\title{
Lava flow hazard at Fogo Volcano, Cabo Verde, before and after the 2014-2015 eruption
}

\author{
Nicole Richter ${ }^{1}$, Massimiliano Favalli ${ }^{2}$, Elske de Zeeuw-van Dalfsen ${ }^{1}$, Alessandro Fornaciai ${ }^{2,3}$, Rui Manuel da Silva \\ Fernandes $^{4}$, Nemesio M. Pérez ${ }^{5,6}$, Judith Levy ${ }^{1}$, Sónia Silva Victória ${ }^{7}$, and Thomas R. Walter ${ }^{1}$ \\ ${ }^{1}$ German Research Centre for Geosciences (GFZ), Potsdam, 14473, Germany \\ ${ }^{2}$ Istituto Nazionale di Geofisica e Vulcanologia (INGV), Pisa, 56126, Italy \\ ${ }^{3}$ Dipartimento di Fisica e Astronomia (DIFA), Alma Mater Studiorum - Università di Bologna, Bologna, 40127, Italy \\ ${ }^{4}$ Instituto D. Luiz, University of Beira Interior, Covilhã, 6201-001, Portugal \\ ${ }^{5}$ Instituto Volcanológico de Canarias (INVOLCAN), 38400 Puerto de la Cruz, Tenerife, Spain \\ ${ }^{6}$ Instituto Tecnológico y de Energías Renovables (ITER), 38611 Granadilla de Abona, Tenerife, Spain \\ ${ }^{7}$ Universidade de Cabo Verde, Praia, Cabo Verde
}

Correspondence to: Nicole Richter (nrichter@gfz-potsdam.de)

Received: 10 March 2016 - Published in Nat. Hazards Earth Syst. Sci. Discuss.: 30 March 2016

Revised: 18 June 2016 - Accepted: 7 July 2016 - Published: 17 August 2016

\begin{abstract}
Lava flow simulations help to better understand volcanic hazards and may assist emergency preparedness at active volcanoes. We demonstrate that at Fogo Volcano, Cabo Verde, such simulations can explain the 2014-2015 lava flow crisis and therefore provide a valuable base to better prepare for the next inevitable eruption. We conducted topographic mapping in the field and a satellite-based remote sensing analysis. We produced the first topographic model of the 2014-2015 lava flow from combined terrestrial laser scanner (TLS) and photogrammetric data. This high-resolution topographic information facilitates lava flow volume estimates of $43.7 \pm 5.2 \times 10^{6} \mathrm{~m}^{3}$ from the vertical difference between pre- and posteruptive topographies. Both the pre-eruptive and updated digital elevation models (DEMs) serve as the fundamental input data for lava flow simulations using the wellestablished DOWNFLOW algorithm. Based on thousands of simulations, we assess the lava flow hazard before and after the 2014-2015 eruption. We find that, although the lava flow hazard has changed significantly, it remains high at the locations of two villages that were destroyed during this eruption. This result is of particular importance as villagers have already started to rebuild the settlements. We also analysed satellite radar imagery acquired by the German TerraSARX (TSX) satellite to map lava flow emplacement over time. We obtain the lava flow boundaries every 6 to 11 days during the eruption, which assists the interpretation and evaluation
\end{abstract}

of the lava flow model performance. Our results highlight the fact that lava flow hazards change as a result of modifications of the local topography due to lava flow emplacement. This implies the need for up-to-date topographic information in order to assess lava flow hazards. We also emphasize that areas that were once overrun by lava flows are not necessarily safer, even if local lava flow thicknesses exceed the average lava flow thickness. Our observations will be important for the next eruption of Fogo Volcano and have implications for future lava flow crises and disaster response efforts at basaltic volcanoes elsewhere in the world.

\section{Introduction}

Effusive volcanic eruptions are associated with lava flows that may cause damage and long-lasting impact on infrastructure and economy. The comune San Sebastiano al Vesuvio in Italy was destroyed by Mount Vesuvius' lava flows in 1944 for the third time in less than 100 years, yet was rebuilt (Kilburn, 2015). In January 2002, lava flows advancing from Nyiragongo Volcano overran the city of Goma in the Democratic Republic of Congo, which was later rebuilt on top of this lava flow (Chirico et al., 2009). Destructive effusive volcanic eruptions also occur frequently at places such as the island of Hawai'i(Kauahikaua and Tilling, 2014; 
Poland et al., 2016), or at Mount Etna, Sicily, Italy (Favalli et al., 2009b). Yet, a common observation in many of these classic examples is that, for various reasons, residents rebuild their houses and return to live in hazardous areas. Studies of effusive eruptions and the mechanisms of lava flow emplacement over time, as well as lava flow hazard assessment and the proposal of risk mitigation strategies, therefore, have developed into fundamental branches of volcano sciences. Recent crises, such as the 2014-2015 Pahoa lava flow crisis at Kîlauea Volcano, Hawai'i (Poland et al., 2016), and the highly destructive 2014-2015 eruption of Fogo Volcano, Cabo Verde (González et al., 2015; Cappello et al., 2016; Bagnardi et al., 2016), have again shown that up-to-date lava flow hazard information is needed in inhabited volcanic environments and that this information has to be effectively communicated to the officials in charge of public safety.

A variety of algorithms have been developed with the common aim of understanding the dynamics of lava flow emplacement, forecasting lava flow paths, and constructing lava flow hazard maps (e.g. Favalli et al., 2005; Harris and Rowland, 2015; Del Negro et al., 2008). These algorithms have been applied to numerous volcanoes, including but not limited to Nyiragongo Volcano, Mount Cameroon, and Mount Etna (Favalli et al., 2009a, 2011b; Tarquini and Favalli, 2011). Modelling techniques follow either the probabilistic or the deterministic approach. The MAGFLOW simulation code (Del Negro et al., 2008) is a deterministic approach that relies on pre-existing knowledge or at least simplified assumptions about the physical and rheological characteristics of flowing lava (Cappello et al., 2015; Tarquini and Favalli, 2015). The FLOWGO model by Harris and Rowland (2015), also a deterministic model, allows for the simulation of changing physical properties, e.g. changes in velocity or thermorheology of flowing basaltic lava following a predefined channel downslope (Harris et al., 2015). Here we use the DOWNFLOW probabilistic code (Favalli et al., 2005) to create lava flow hazard maps. Based on the law of gravitation, DOWNFLOW follows the simple assumption that lava flows downhill from an eruption site. One main advantage of this code over deterministic models is that only basic physics applies, therefore no pre-existing knowledge or assumptions on physical properties of the lava flows are needed. The most important input for the DOWNFLOW simulation is an accurate and up-to-date digital elevation model (DEM) and the location of the eruptive vent.

High-resolution topographic information does not only serve as an essential prerequisite for lava flow simulations, it is also one of the first requirements for any effusive eruption as it allows for lava flow thickness and volume estimates. Modern remote sensing techniques, such as photogrammetry, airborne and terrestrial light detection and ranging (lidar), terrestrial laser scanning, and synthetic aperture radar interferometry (InSAR) are among the most commonly used sources of terrain information for detailed analyses of the Earth's surface. Major differences between these methods relate to the achievable spatial resolution and coverage, as well as information quality and accuracy. The decision of which method to use highly depends on the specific application and the user's needs. Modern high-resolution satellite systems, such as Pléiades (optical) and TanDEM-X (radar), need to be tasked to acquire topographic data in response to a volcanic crisis. Updates of pre-existing topographic information can also be achieved using ground-based technologies, such as terrestrial laser scanning and camera- or drone-based photogrammetry. These methods are often more flexible than satellite observations with respect to the acquisition time and date. For instance, we produced a posteruptive DEM from ground-based data in January 2015, while the next (and only other) available posteruptive DEM data were acquired more than 5 months after the end of the 2014-2015 eruption (on 20 June 2015) by the Pléiades satellite (Bagnardi et al., 2016). TanDEM-X bistatic data are not available for Fogo after the 2014-2015 eruption. Ground-based techniques are especially effective for effusive volcanic eruptions, where only the directly affected areas need to be updated. The potential of very long-range terrestrial laser scanner (TLS) instruments to survey the dynamics of active lava flow fields and to map the topographic changes associated with the emplacement of new flows was shown at Mount Etna, Italy (James et al., 2009). We produced the first posteruptive topographic map of the 2014-2015 Fogo lava flow using TLS and ground-based photogrammetric data in order to update a pre-eruptive photogrammetric DEM of Fogo Island, both featuring a $5 \mathrm{~m}$ spatial resolution. We estimated lava flow characteristics, such as lava flow thickness and volume. We also generated and compared pre- and posteruptive lava flow hazard maps.

\section{Geologic setting and eruptive history}

Fogo Island is one of the youngest volcanic islands of the Cabo Verde archipelago in the Atlantic Ocean and is built up from the remnants of one single giant volcano, known as the Monte Amarelo Volcano (Day et al., 1999). The eastern coastline reflects a catastrophic flank collapse event in the island's geologic history (Day et al., 1999; Ramalho et al., 2015), which is thought to date back $\sim 73 \mathrm{ka}$ (Ramalho et al., 2015). This event left a prominent east facing, extremely steep collapse structure, the Monte Amarelo escarpment or Bordeira. It reaches a height of up to $1000 \mathrm{~m}$ above the relatively flat, $9 \mathrm{~km}$-wide, $\mathrm{N}-\mathrm{S}$ elongated, caldera-like plain, called the Chã das Caldeiras (Chã). The Chã is located at an average elevation of $\sim 1700 \mathrm{~m}$ and covers an area of $\sim 35 \mathrm{~km}^{2}$ (Fig. 1). To the east the Chã is bound by the highest point of the island, the Pico do Fogo stratocone (2829 m). The WSW flank of Pico do Fogo was active from a smaller cone, Pico Pequeno, during both the 1995 and 2014-2015 eruptions (Fig. 1).

Since the time of Portuguese discovery and settlement in $\sim 1500 \mathrm{AD}$ (e.g. GVP, 2014), about 27 eruptions have oc- 

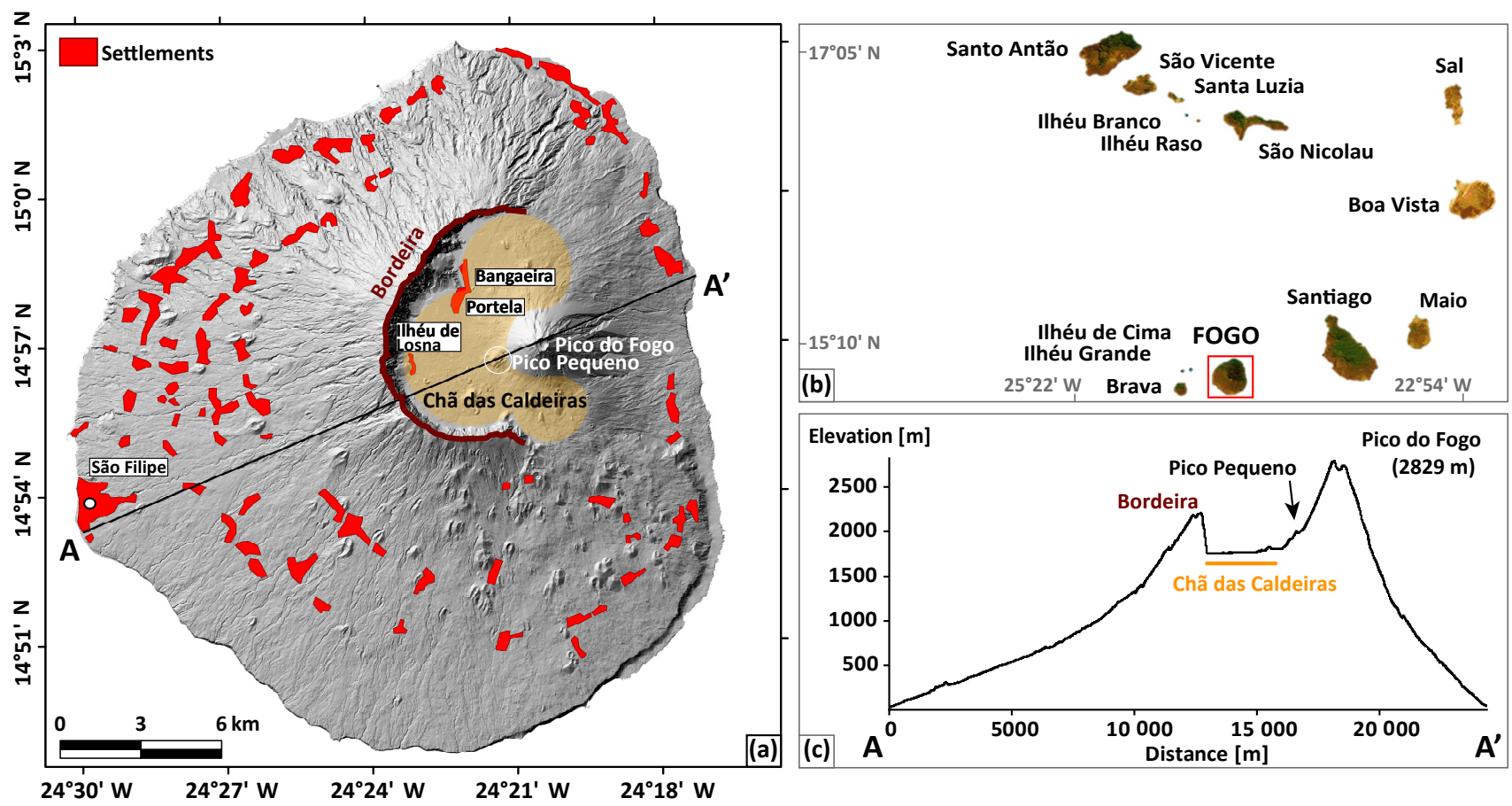

Figure 1. Map of Fogo Island (a), one of the 14 volcanic islands of the Cabo Verdean archipelago (b), and profile A-A' cutting through the lowest point of the Bordeira wall (c), while the maximum elevation of a point along the Bordeira wall is $2692 \mathrm{~m}$. The settlements (red areas) were downloaded from the Copernicus Emergency Management Service (2014), the small settlement of Ilhéu de Losna was added manually to the map.

curred on Fogo Volcano (Ribeiro, 1960; Day et al., 2000). In 1680 a major eruption was associated with strong earthquakes and caused people to flee the island temporarily, according to historic records (Ribeiro, 1960; Day et al., 2000). The last major activity at the summit of Pico de Fogo dates back to 1725 (Day et al., 1999); recent activity at the summit is limited to high temperature fumaroles, diffuse degassing, and thermal energy release (Dionis et al., 2015). The 1785, $1799,1816,1847,1852$, and 1857 flank eruptions produced lava flows travelling seawards on the eastern flank of the volcano. In the 1860s the first settlements were established within the Chã, likely because of the abundance of fertile volcanic soils. The three most recent eruptions (which occurred in 1951, 1995, and 2014-2015) took place within the Chã, where villages and agricultural lands were affected (GVP, 2013; Torres et al., 1997 in Texier-Teixeira et al., 2014).

On 2 April 1995 a fissure eruption started at Pico Pequeno (Amelung and Day, 2002), a small cone WSW of Pico do Fogo (Fig. 1). All residents were evacuated, but houses as well as $\sim 4.3 \mathrm{~km}^{2}$ of agricultural land were destroyed (GVP, 1995a). The total area covered by lava flows during this eruption was estimated to be around $4.7 \mathrm{~km}^{2}$ (Amelung and Day, 2002). The flow thickness ranged between $\sim 1$ and $\sim 20 \mathrm{~m}$ (GVP, 1995b; Worsley, 2015). After a period of increased strombolian activity, the eruption ended on 26 May 1995. Because some of the best farmland on the island is located within the Chã, people moved back after the eruption despite attempts from officials to relocate the population.

Almost 20 years later, on 23 November 2014, a new eruption started at Pico Pequeno with the opening of a fissure located $\sim 200 \mathrm{~m}$ south-east and roughly in parallel to the 1995 fissure (González et al., 2015). At first, six active vents emitted lava fountains, ash, and gas. Later on, activity was focused at one major vent (located at $24.35341^{\circ} \mathrm{W}$ and $14.9446^{\circ} \mathrm{N}$ ) (Silva et al., 2015). Lava flows were emitted from the base of Pico Pequeno and travelled to the southwest before splitting into two main lobes that we will refer to as the north-west (NW) and south (S) lava lobes throughout this paper. The main road and evacuation route out of the Chã was already cut off 2 days after the eruption had started and the residents of the Chã were forced to transport their movable property uphill before being evacuated from the area (Fig. 2a). The NW lava lobe continued to engulf Portela and Bangaeira in early December 2014 and then gradually ceased (Fig. 2b). However, a new lava lobe split from the NW lobe closer to the eruption site and advanced westward towards the Bordeira wall (referred to as the $\mathrm{W}$ lobe throughout this paper). This lava lobe split into a northern and a southern branch close to the Bordeira wall and covered the houses of the small agricultural settlement of Ilhéu de Losna. In early 2015, effusive activity was replaced by increased strombolian explosions at the vent (cf. Appendix A) before the erup- 


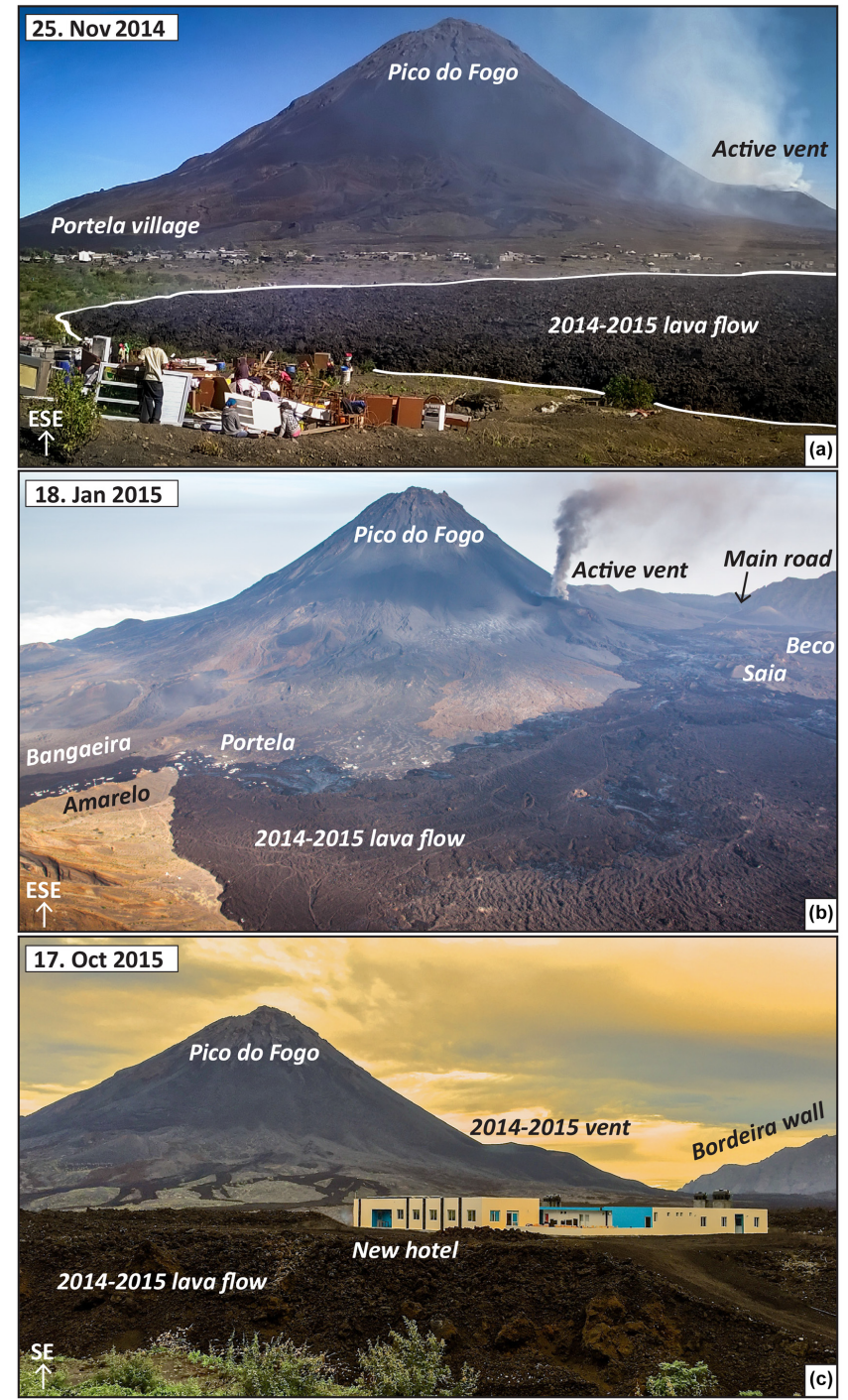

Figure 2. Photographs taken during (a and b) and after (c) the 2014-2015 Fogo eruption. On 25 November 2014, the village of Portela was not yet engulfed by lava flows, but private belongings were brought to higher ground (a), while on 18 January 2015 lava flows were covering the villages of Portela and Bangaeira (b). In early October 2015, a new hotel opened which is built on the 20142015 lava flow ( ${ }^{\circledR}$ Mustafa Kerim Eren) (c).

tion ended on 8 February 2015 (GVP, 2014). Shortly after the end of the 2014-2015 eruption, reconstruction of buildings and infrastructure within the Chã had started again (Fig. 2c), despite renewed efforts from officials to suppress permanent residence within the Chã.

After the 1995 Fogo eruption, lava flow simulations were tested based on a $15 \mathrm{~m}$ Digital Terrain Model (DTM) (Quental et al., 2003). The Cellular Automata (CA) technique was applied to simulate the time- and space-dependent flow emplacement. Results were in agreement with the actual lava flow coverage, but only the first 2 days of the 1995 erup- tion were reproduced successfully. A general, yet provisional, volcanic hazard map for the scenario of a renewed phreatomagmatic explosive eruption comparable to the major 1680 eruption was provided by Jenkins et al. (2014) on the base of investigations by Day and Faria (2009, unpublished data). This map suggested that the entire area of the Chã as well as the eastern flank of the volcano were areas of high hazard resulting from lava flows, $2-10 \mathrm{~m}$ ash fall, possible pyroclastic surges, and rock avalanches. Furthermore, Cappello et al. (2016) used HOTSAT satellite data and the physically based MAGFLOW model to simulate the lava flow emplacement during the ongoing 2014-2015 eruption. In the study at hand, we constructed probabilistic lava flow hazard maps for the Chã das Caldeiras and the eastern flank of Fogo Volcano. We were particularly interested in whether the 2014-2015 eruption has significantly changed the lava flow hazard in the affected areas, as this has important implications for temporal and spatial changes of lava flow hazards in general.

\section{Data and methods}

One of the first requirements for an effusive crisis is an up-todate model of the new topography. In response to the 20142015 Fogo eruption, a Hazard and Risk Team (HART) of the German Research Centre for Geosciences (GFZ) processed high-resolution satellite radar data and went to Fogo Island in order to acquire high-resolution topographic data between 11 and 21 January 2015. The topographic data are needed to estimate lava flow characteristics, such as erupted volumes, and serves as the most crucial input data for our lava flow simulations and hazard assessment. The frequent synthetic aperture radar (SAR) satellite data acquisitions allow us to map lava flow emplacement over time, information that helps us to better understand the lava flow model performance.

\subsection{SAR data}

We used SAR data acquired by the German satellite TerraSAR-X (TSX) to monitor the emplacement of the 2014-2015 lava flow. The TSX satellite operates at a wavelength of $3.1 \mathrm{~cm}$ (X-band) of the electromagnetic spectrum. The data were acquired in the satellite's SpotLight mode $(\sim 1 \mathrm{~m}$ spatial resolution, scene size $\sim 10 \mathrm{~km} \times \sim 10 \mathrm{~km})$, horizontal polarization and have a repeat time of 11 days. TSX data are acquired over Fogo Island on four tracks, two ascending (orbital paths 57, incidence angle $53.5^{\circ}$ and 148 , incidence angle $38.9^{\circ}$ ) and two descending (orbital paths 64 , incidence angle $27.9^{\circ}$ and 155 , incidence angle $46.3^{\circ}$ ). We use coherence measurements to monitor lava flow emplacement every 6 days between 14 November 2014 and 28 December 2014 (i.e. the early, highly effusive phase of the eruption) and every 11 days thereafter until 10 February 2015. 
Interferometric coherence is a measure of the correlation between the phase components of two SAR images of the same track (i.e. the same viewing geometry) (Hanssen, 2001). Coherence values range from 0 (low coherence, decorrelation) to 1 (high coherence, strong correlation between SAR acquisitions). As a consequence of the time delay between two acquisitions (11 days for TSX), temporal decorrelation occurs in repeat-pass InSAR as the scatterers within a resolution cell move, change their dielectric properties, or are replaced by a new set of scatterers (e.g. upon lava flow emplacement or ash deposition) (e.g. Zebker et al., 1996). As the Chã is sparsely vegetated, decorrelation in the study area is mostly associated with steep slopes and surface changes.

\subsection{Topographic data}

We created an updated DEM for Fogo Volcano, which is composed of three different data sets: firstly, a commercial pre-eruptive DEM acquired by GRAFCAN (Sect. 3.2.1); secondly, our TLS DEM that is composed of eight combined point clouds that cover in total $87.7 \%$ of the 20142015 lava flow (Sect. 3.2.2); and finally, four separate, very small DEMs produced by applying the structure from motion (SfM) method to optical camera data (Sect. 3.2.3) in order to fill the remaining gaps. We merged the data sets by minimizing the vertical distance between our TLS and SfM point clouds and the commercial pre-eruptive reference DEM using the Minuit minimization tool (Sect. 3.2.4).

\subsubsection{Pre-eruptive data}

We use a commercial pre-eruptive DEM of Fogo Island featuring a $5 \mathrm{~m}$ pixel spacing that was generated from contours on the base of photogrammetric data. The DEM was georeferenced using a limited number of points acquired during a mapping campaign in 2003-2004. According to GRAFCAN, the company who generated the DEM, the horizontal and vertical accuracies are 40 and $50 \mathrm{~cm}$ respectively. However, the data were delivered in integer values. We therefore expect the accuracy to be smaller. From the delivered DEM grid we generated contour lines with $1 \mathrm{~m}$ spacing (in elevation) and reinterpolated the surface.

\subsubsection{Posteruptive TLS data}

We used a TLS instrument of the type Riegl VZ-6000, with the capability to produce submetre resolution topographic data of target objects at a maximum distance of $6000 \mathrm{~m}$ from the scanner position. The instrument combines the 3-D laser scanning and laser ranging techniques. Data are acquired by the controlled deflection of a laser beam into different directions by means of an oscillating mirror, and the $360^{\circ}$ rotation of the scanner's head (3-D laser scanning). The distances for each point in the point cloud are determined by measuring the time delay between the emission of the laser pulses and

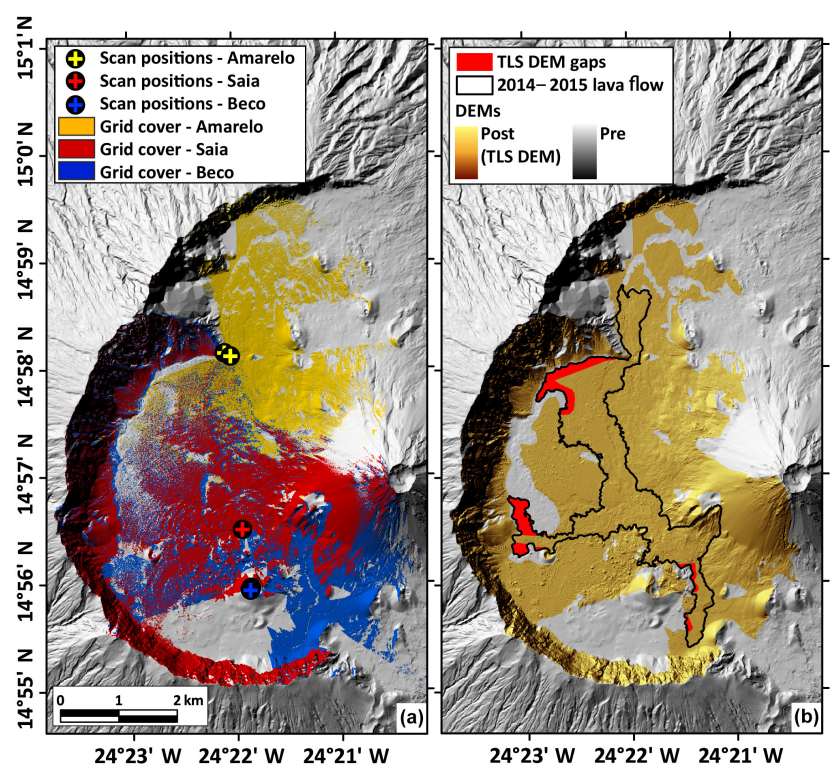

Figure 3. Coverage of the TLS data sets (in grid format) and corresponding scanner locations on Monte Saia, Monte Beco, and Monte Amarelo (a) and coverage of the final TLS DEM (b), where red shapes mark areas of the 2014-2015 lava flow (black polygon) that are not covered by the final TLS DEM. These gaps were filled using the SfM method on optical camera data.

the reception of the target echoes (laser ranging). The coordinates of each single point are collected relative to the origin, along with additional attributes, e.g. reflectance and amplitude. The raw point cloud is stored in a local, scanner-centred coordinate system (Riegl, 2013).

During the field campaign in January 2015, we acquired eight TLS point clouds, which were used for the generation of the updated topographic map (Table 1). We chose three main scanner locations, namely Monte Beco, Monte Saia, and Monte Amarelo (Fig. 3a). The terrestrial laser scanning technique is commonly associated with the occurrence of shadow areas due to the acquisition geometry. We minimized the shadow effects by scanning from slightly different positions with different fields of view at Monte Beco and Monte Amarelo so that our TLS data points cover $87.7 \%$ of the area overrun by the 2014-2015 lava flow and most of the Chã. We combined the individual scans for these two main scan locations separately by means of a minimum of three common tie points (reflectors) that we installed in the field. Rough orientation of the point clouds was done using handheld GPS positions of the reflectors. At five of the scanner positions (one on Monte Saia and four on Monte Beco), we acquired differential GPS data (Table 1); all other scanner positions were collected by the scanners internal, less precise GPS instrument. Differential GPS data (where acquired) were collected for at least $1 \mathrm{~h}$ (up to $3 \mathrm{~h} 30 \mathrm{~min}$ ) and at one site (SAIA1) data were acquired on 2 different days. Differential GPS processing was done in two main steps. At first, the aver- 


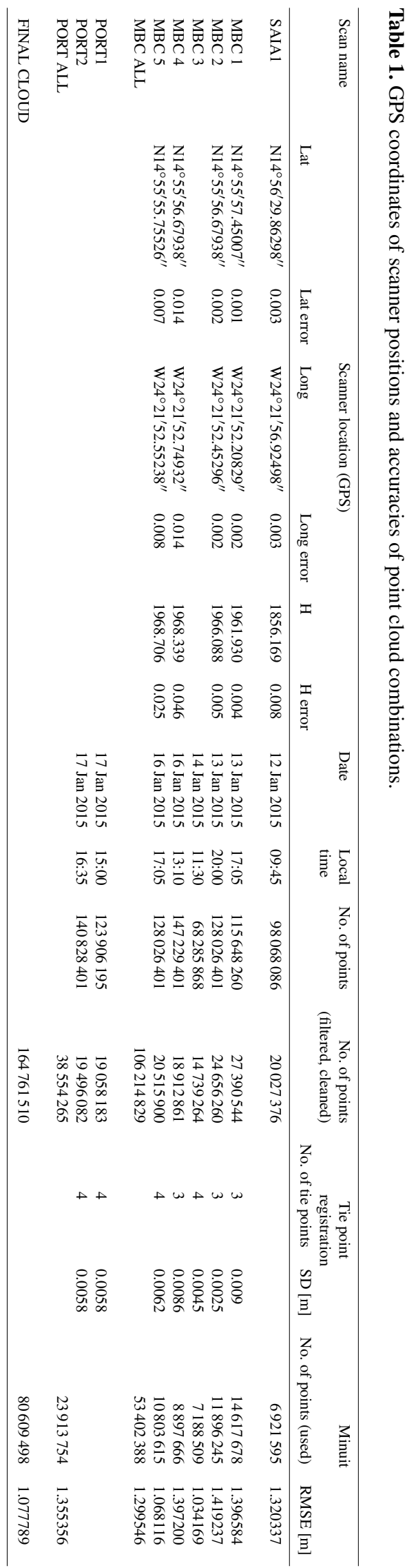

age positions of a network of seven permanently installed GPS stations were estimated with respect to the ITRF2008 global reference frame (Altamimi et al., 2011). These stations were installed and maintained by $\mathrm{C} 4 \mathrm{G}$ (Co-laboratory for Geosciences, Portugal) and INMG (Instituto Nacional de Meteorologia e Geofísica, Cabo Verde) and continuously acquired GPS data during the 2014-2015 Fogo eruption (Fernandes et al., 2015). The computation of the reference positions was done using the precise point positioning strategy (PPP) implemented in the GIPSY-OASIS software package (Zumberge et al., 1997). More details on the methodology used here are provided by Neves et al. (2014). Secondly, the coordinates of the TLS stations were estimated with respect to the permanent network using the TBC (Trimble Business Center) software. This software allows for the adjustment of the position of the TLS sites by estimating the baselines between all simultaneously observed points. Scanner locations and the coverage of the acquired point clouds are shown in Fig. 3a. Details on the scanner positions, and tie point registration accuracies are listed in Table 1.

\subsubsection{Posteruptive photogrammetric data}

Photogrammetric data were collected from positions along the upper Bordeira ridge using dSLR 15.1-megapixel Canon EOS Rebel cameras with CMOS sensor. We used the SfM method as introduced by Verhoeven (2011) to generate four small DEMs from a total of 77 camera images. A first, rough georeferentiation was performed using manually selected ground control points (GCPs) before following the error minimization procedure described below. This way we were able to fill $92 \%$ of the remaining TLS data gaps (red areas in Fig. 3b).

\subsubsection{Data merging}

In order to merge the separate point clouds a common reference frame was needed. We therefore minimized the root mean square error (RMSE) between the TLS and SfM point clouds and a reference DEM using the Minuit2 5.18/00 package, developed at CERN (James and Winkler, 2004 and references therein). Minuit is a tool to find the minimum value of multi-parameter functions and can be freely downloaded (http://www.cern.ch/minuit). Throughout this paper we will refer to RMSE to actually address the root mean square residuals (in elevation) between our data and the reference DEM, rather than a true absolute error of our data. We used the pre-eruptive DEM as a reference for our point clouds. For the minimization procedure, the Bordeira wall (which is well covered by the TLS point clouds, but mainly interpolated within the pre-eruptive DEM), as well as the area covered by the 2014-2015 lava flow, were masked out from the preeruptive DEM. Therefore, the number of points that were used for the Minuit minimization is smaller than the total number of points in the point clouds (cf. Table 1, columns 
"No. of points (used)" vs. "No. of points (filtered, cleaned)"). For those five scans, where accurate GPS locations were available, we fixed the centre of rotation and translation of the cloud at the scanner position. Otherwise all rotation parameters (i.e. rotation around $x$ (roll), $y$ (pitch), $z$ (yaw)) and the centre of rotation and translation were kept free to adjust. Iterative runs of the Minuit minimization function were used to decrease the RMSEs. The final minimum RMSEs for the individual and combined point clouds are listed in Table 1 . We generated a DEM featuring a $5 \mathrm{~m}$ spatial resolution from more than 164 million TLS data points and combined it with the pre-eruptive DEM. This initial posteruptive DEM was used as a reference DEM for the SfM point clouds (using masks for the areas that were not covered by the TLS data). The achieved Minuit accuracies for the four individual SfM DEMs are listed in Table 2. The masks that were used to estimate the Minuit RMSEs are illustrated in Appendix B. In a last step the initial posteruptive DEM was updated using the SfM DEM patches.

\subsection{DOWNFLOW simulation of the 2014-2015 lava flow and model calibration}

In order to assess the lava flow hazard at Fogo Volcano, Cabo Verde, we used the probabilistic lava flow simulation code DOWNFLOW (Favalli et al., 2005). A lava flow simulation follows a number of $N$ steepest descent paths (runs) originating from a known vent location. At each pixel of the DEM grid that is inundated by a lava flow, and for each run, a random perturbation within a given interval $\pm \Delta h$ is introduced in order to allow widening, branching, and overcoming of small obstacles. The parameter $\Delta h$ is the critical parameter that needs to be assessed for each individual volcano. Multiple test runs and a tuning process were performed to find the best fit between the model runs and the coverage of the real lava flow of Fogo Volcano (Fig. 4). Along a steepest descent path, topographic lows are filled by depositing a certain thickness when the simulation runs into a local minimum. A local minimum is reached if after (in our case) 10 iterations of random perturbation a simulation cannot find a steepest descent path to follow downslope. Typically a very small thickness is added (in our case $0.01 \mathrm{~m}$ ) during iterations. This value can be adjusted in the DOWNFLOW input file. The smaller the value, the longer it will take for the simulation to run, but the better the filling. More details on the DOWNFLOW simulation are described by, e.g. Favalli et al. (2005, 2011a) and Tarquini and Favalli (2015).

The coordinates $24.35341^{\circ} \mathrm{W}$ and $14.9446^{\circ} \mathrm{N}$ at an elevation of $1995 \mathrm{~m}$ a.s.l. were chosen as the source location of the lava flow that erupted on 23 November 2014, based on our high-resolution posteruptive TLS DEM. It is important to mention that we did not apply a lava flow length constraint at this point, meaning that we did not stop the lava flow simulation when it reached a certain length.

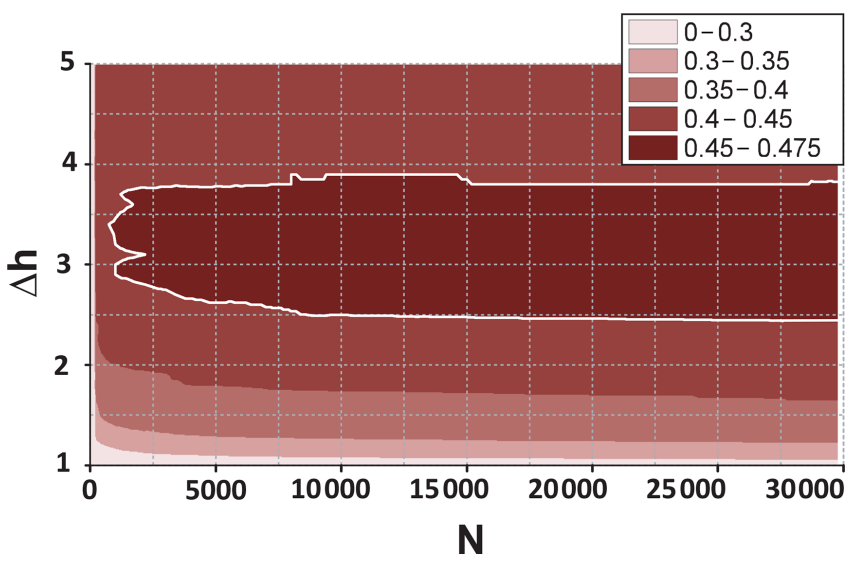

Figure 4. DOWNFLOW calibration. The maximum fitness of $\mu=0.47$ is achieved using a parameter $\Delta h=3 \mathrm{~m}$. We chose $N=10000$ as this guarantees short computing times while maintaining statistical robustness.

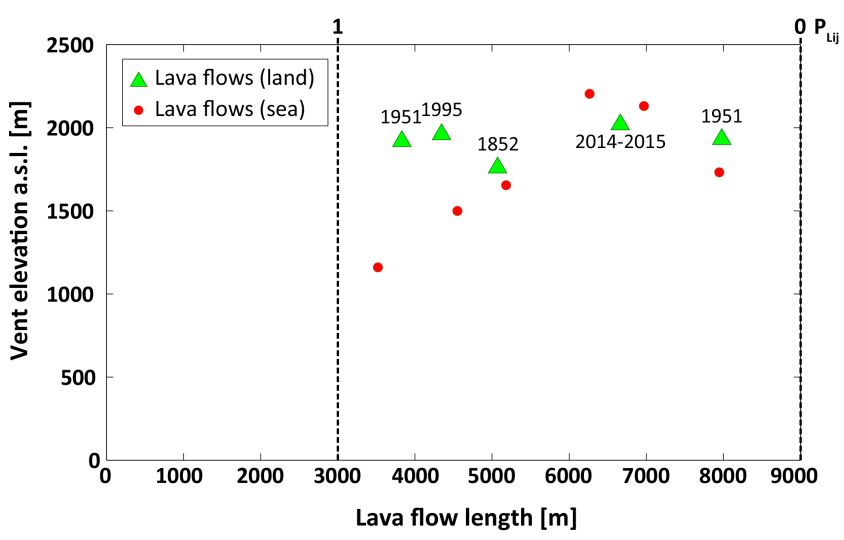

Figure 5. Lava flow length constraint. Green triangles show the vent elevation and lava flow lengths of lava flows that stopped on land (including the year of the eruption). Corresponding vent locations are given in Fig. 6. Red points indicate lava flows that reached the ocean.

For calibration we analysed the whole parameter space in order to maximize the fit, $\mu$, between the real lava flow and the DOWNFLOW simulation. As we do not implement a length constraint at this point, the simulation is cut to the length of the real lava flow. The parameters to be calibrated are $\Delta h$ and $N$. The fit, $\mu$, is calculated according to the following equation:

$\mu=\frac{A_{\mathrm{S}} \cap A_{\mathrm{R}}}{A_{\mathrm{S}} \cup A_{\mathrm{R}}}$,

where $A_{\mathrm{S}}$ is the area covered by the simulation and $A_{\mathrm{R}}$ is the area covered by the real lava flow. Figure 4 shows the DOWNFLOW calibration for the 2014-2015 Fogo eruption. According to the graph, the value of $N$ is not critical for the fit $\mu$, while for $\Delta h<2.5 \mathrm{~m}$ and $\Delta h>4 \mathrm{~m}$ the fit significantly decreases. We choose the value $N=10000$ because 
Table 2. Acquisition and processing of SfM data.

\begin{tabular}{|c|c|c|c|c|c|c|}
\hline SfM Patches & Date & Camera & No. of images & No. of points & No. of points used (mask) & Minuit RMSE \\
\hline NW lobe & 18 Jan 2015 & Canon EOS REBEL T3i & 12 & 1134322 & 834649 & 0.750539 \\
\hline S lobe (north) & 19 Jan 2015 & Canon EOS REBEL T1i & 48 & 431340 & 29219 & 1.791653 \\
\hline S lobe (south) & 19 Jan 2015 & Canon EOS REBEL T1i & 48 & 431340 & 27252 & 0.694206 \\
\hline W lobe & 18 Jan 2015 & Canon EOS REBEL T1i & 17 & 1003348 & 251517 & 1.452028 \\
\hline
\end{tabular}

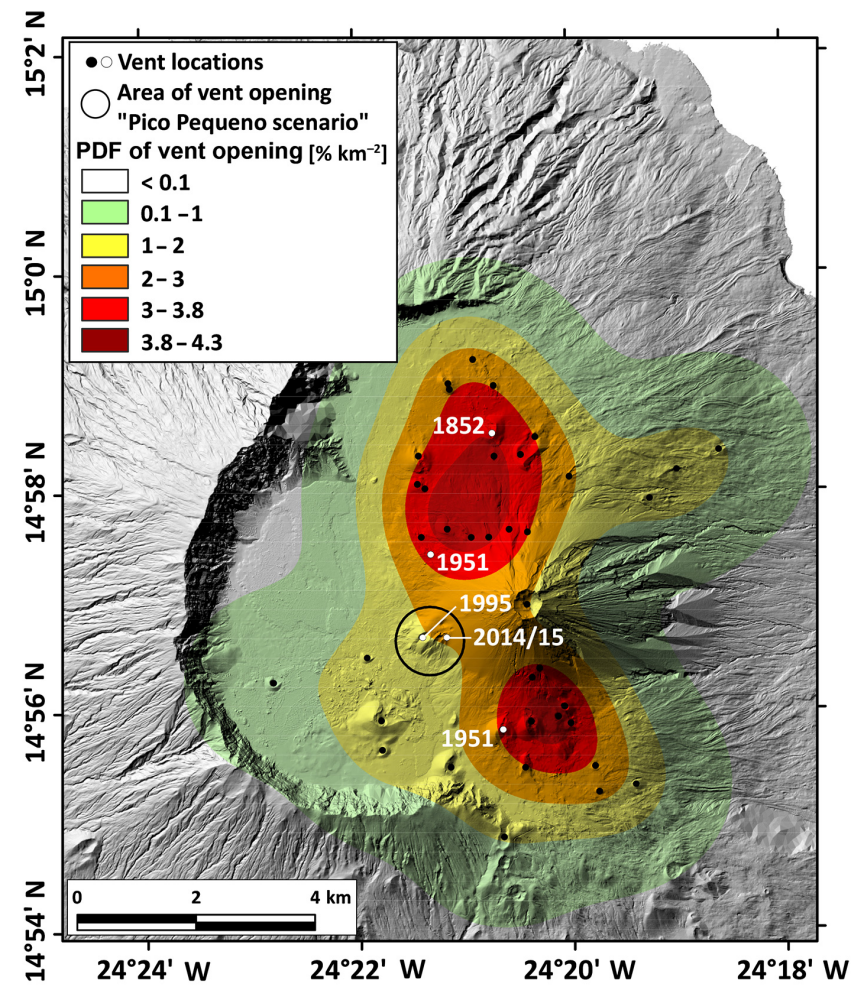

Figure 6. Probability distribution of future vent opening for the Fogo scenario. White points mark the locations (and eruption years) of historic vents producing lava flows that stopped on land. Black dots mark locations of historic vents producing lava flows that reached the ocean. The black circle around Pico Pequeno indicates the PDF domain for the Pico Pequeno scenario.

this number is a compromise between low computational time and statistical robustness (Favalli et al., 2009a). The maximum fitness of $\mu=0.47$ is achieved using a parameter $\Delta h=3 \mathrm{~m}$.

\subsection{Hazard map generation}

Using a single DOWNFLOW simulation we reconstructed the 2014-2015 lava flow which originated from a known vent (Sect. 3.3). The simulation of a future scenario requires a fundamental lava flow hazard assessment; this includes the simulation of lava flows for all possible future vents. In order to create meaningful hazard maps, these simulations need to be weighted by two factors: (a) the lava flow length constraint,

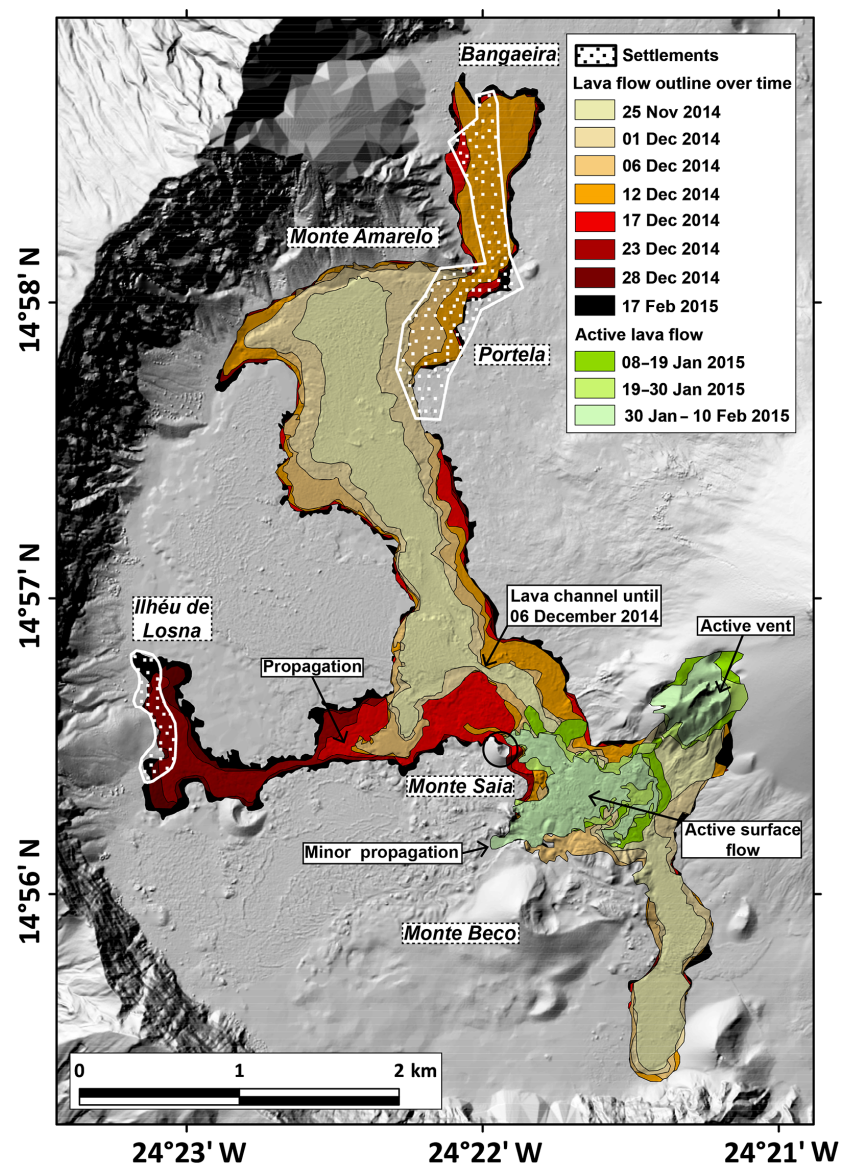

Figure 7. Lava flow outline over time from TerraSAR-X coherence maps (cf. Appendices C and D).

in order to stop the flows before they reach the end of the data set (Sect. 3.4.1) and (b) the probability function of future vent opening, because in reality a vent opening at some locations is more likely than at others (Sect. 3.4.2).

\subsubsection{Lava flow length constraint}

We apply a lava flow length constraint that is based on information about historic eruptive vent locations and corresponding lava flow lengths. For other volcanoes it was shown that a negative correlation exists between vent elevation and lava flow lengths, e.g. at Mount Etna (Favalli et al., 2009b), Nyiragongo Volcano (Favalli et al., 2009a), and 
Mount Cameroon (Favalli et al., 2011b). According to these examples, vents located at higher elevations tend to produce shorter lava flows. For Fogo Volcano, we use a geologic map as a base of information (Torres et al., 1997 in TexierTeixeira et al., 2014). We also take into account an updated map published recently by Carracedo et al. (2015). We georeferenced the maps, determined the historic vent locations, and plotted the vent elevations against the lengths of the corresponding lava flows (Fig. 5). This plot distinguishes lava flows that reached the sea from lava flows that stopped onshore. While the first only helped to find the minimum lava flow length, the latter were used as the base for the length constraint. A Fogo-specific limitation is that we only have a record of five historic lava flows that did not reach the sea, and all of the corresponding vents are located within a narrow elevation range of less than $300 \mathrm{~m}$ (between 1760 and $2020 \mathrm{~m}$ a.s.1.). Therefore, we cannot infer a negative correlation between vent elevation and corresponding lava flow lengths. Instead, we consider a constant distribution of lava flow lengths in between a minimum $(3000 \mathrm{~m})$ and a maximum $(9000 \mathrm{~m})$ lava flow lengths. This means that we assume that a point that lies within $3000 \mathrm{~m}$ downflow from a given vent will always be invaded (probability $=1$ ) and this probability linearly decreases to 0 for a downflow distance of $9000 \mathrm{~m}$. The minimum and maximum values were chosen by applying a buffer zone to the observed minimum and maximum lava flow lengths given by the average distance between consecutive flow lengths (approximately $1000 \mathrm{~m}$ ).

\subsubsection{Probability density function of vent opening}

We base the probability of vent opening on the record of historic vents assuming that future vents are more likely to open in areas where historic vents cluster. The vent locations were selected on the basis of our posteruptive DEM and the geologic map of Fogo Volcano (Torres et al., 1997 in Texier-Teixeira et al., 2014). They were used to estimate the probability density function (PDF) of vent opening by applying a Gaussian smoothing kernel with a bandwidth of $800 \mathrm{~m}$ (Bowman and Azzalini, 2003; Favalli et al., 2011b). Bartolini et al. (2013) suggested a method for finding the optimal bandwidth of a Gaussian smoothing kernel. According to their approach, the optimal bandwidth for our Fogo case study would be $3600 \mathrm{~m}$. This would result in one maximum in our distribution, centred on the Pico do Fogo stratocone. However, realistically it is unlikely Pico do Fogo represents the maximum probability of vent opening. Therefore, we decided to find the best bandwidth by trials in order to avoid over- or undersmoothing.

We describe two different scenarios and create the corresponding hazard maps, namely the "Pico Pequeno scenario" and the "Fogo scenario". The first scenario considers a vent opening at Pico Pequeno. We consider a future vent opening at this location to be a likely future scenario, as the two most recent eruptions occurred from Pico Pequeno. For this scenario the entire PDF domain is a circle of $1150 \mathrm{~m}$ in diameter centred between the 1995 and 2014-2015 vents (circle in Fig. 6). We consider a PDF that is constant inside this circle and 0 outside. The second scenario applies to Fogo Volcano as a whole. For the Fogo scenario, 42 vents within the Chã were considered (Fig. 6) as we do not have any record of historic eruptions outside the Chã. In the Fogo scenario (Fig. 6), the area at and around Pico Pequeno (as indicated by the circle) has an overall probability of vent opening of $\sim 2 \%$.

\subsubsection{Probability of lava flow invasion}

We create lava flow hazard maps for Fogo Volcano that show the probability $H_{i}$ of any pixel $i$ to be inundated by a future lava flow, before knowing where the vent will be located. This $H_{i}$ is calculated from a product of probabilities $(P)$ and is given by the following equation (Favalli et al., 2011b):

$H_{i}=\sum_{j} \rho_{V j} \Delta x \Delta y \cdot P_{i j} \cdot P_{L i j}$,

where the sum extends over all possible vent locations $j$ with the coordinates $x_{j}$ and $y_{j}$, and $\rho_{V j} \Delta x \Delta y$ represents the probability of vent opening inside the pixel $j$ (cf. Sect. 3.4.2 and Fig. 6). The PDF $\rho_{V j}$ is a probability divided by an area; therefore, the dimensions of the resolution cell, $\Delta x$ and $\Delta y$, need to be taken into account. $P_{i j}$ is a mask that will have the value 1 , if a DOWNFLOW simulation starting from the vent $j$ covers the pixel $i$, otherwise $P_{i j}$ will be 0 . Finally, $P_{L i j}$ represents the lava flow length constraint (cf. Sect. 3.4.1 and Fig. 5) and gives the probability that a DOWNFLOW simulation will reach pixel $i$ when originating at vent $j$. Following Fig. 5, $P_{L i j}=1$ at a length of $\leq 3000 \mathrm{~m}, P_{L i j}=0$ at a length of $\geq 9000 \mathrm{~m}$, and $P_{L i j}$ is interpolated between 3000 and $9000 \mathrm{~m}$. For the Fogo scenario, we consider $82000 \mathrm{fu}-$ ture vents, i.e. one vent every $50 \mathrm{~m}$, distributed on a square mesh. For the Pico Pequeno scenario, 413 vents were taken into account within the given circle as indicated in Fig. 6.

In practice this means we perform 82000 DOWNFLOW simulations, each with $N=10000$ and $\Delta h=3 \mathrm{~m}$, and store them in a simulation database. For a given simulation database (i.e. a defined, fixed $P_{i j}$ ), all other parameters of the equation above are easily adjustable. Consequently, we can investigate different scenarios by changing the lava flow lengths constraint or the vent opening PDF. The hazard maps for the Pico Pequeno and Fogo scenarios, for example, are created using two different vent opening PDFs.

Furthermore, lava flow hazard maps are created for two time steps based on the two available DEMs; the pre-existing, pre-eruptive DEM is used to reconstruct the 2014-2015 lava flow and assess the pre-eruptive lava flow hazard within the Chã and on the eastern flank of the volcano. We then repeat the same simulations using the updated DEM. We assess to what extent the most recent eruption has changed the probability of lava flow inundation in the affected area and the whole eastern part of the island. 

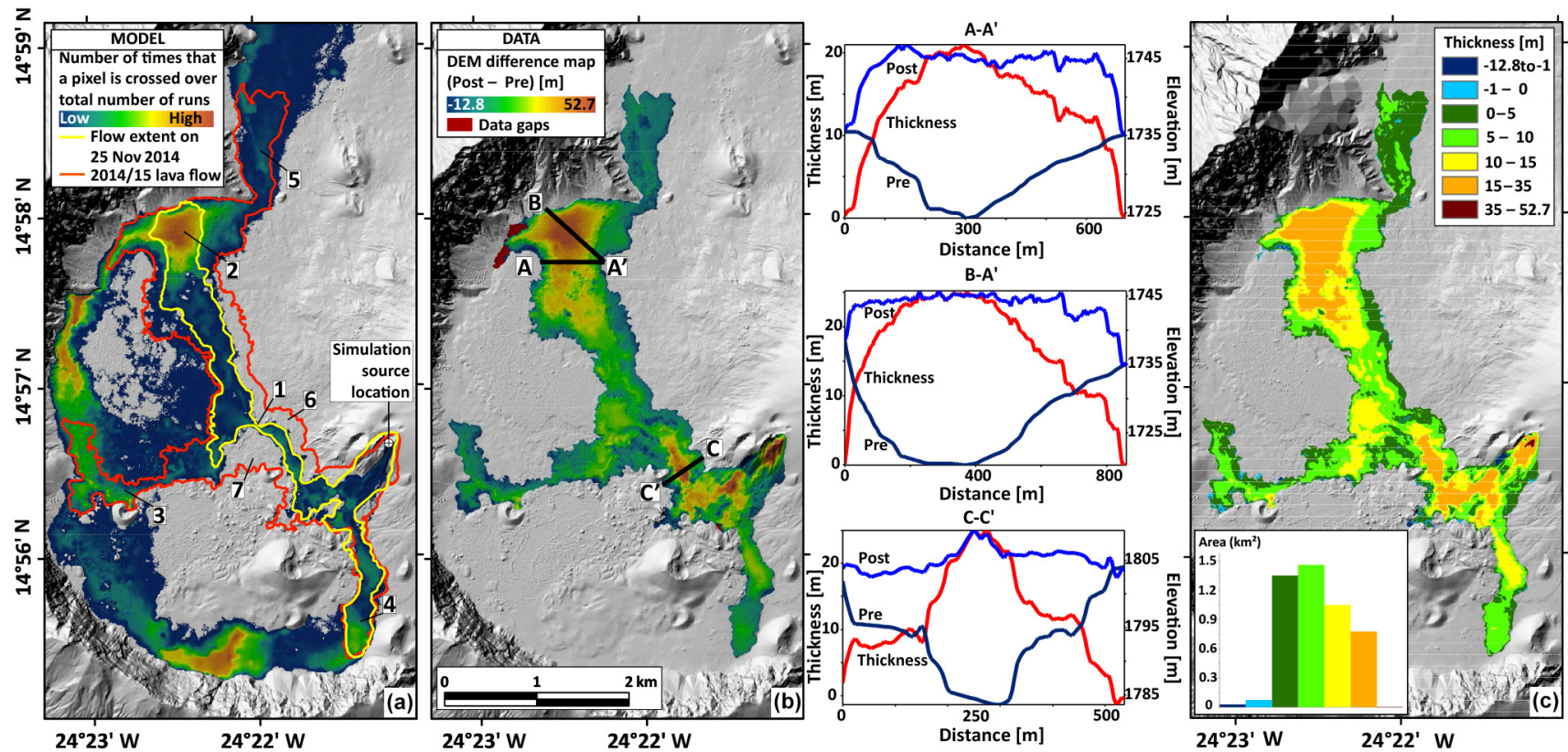

Figure 8. Comparison of the DOWNFLOW reconstruction of the 2014-2015 lava flow (a), and the lava flow thickness (DEM difference map) (b). Profiles compare pre- and posteruptive topographies and the lava flow thickness. Panel (c) shows the classified thickness map and the corresponding histogram (inset).

\section{Results}

\subsection{Lava flow mapping from satellite radar data}

Figure 7 shows the areal coverage of the 2014-2015 lava flow over time as mapped using TerraSAR-X coherence images (provided in Appendix D). This map shows that the NW lava lobe had already travelled almost $4 \mathrm{~km}$ within the first 2 days of the eruption, but had not quite reached the village of Portela yet. The S lava lobe was also already emplaced. It did not advance much after emplacement, except for some minor widening. Between 25 November 2014 and 1 December 2014, primarily the NW lava lobe widened, destroying the first houses of Portela. We also observe minor propagation and widening at the $\mathrm{W}$ lava lobe. This trend of widening and engulfing more houses of Portela continued throughout 6 December 2014. Until that time, lava flowed in a welldefined channel north of Monte Saia (cf. Fig. 8a, point \#1 and Fig. $8 b$, profile $C-C^{\prime}$ ). According to our coherence analysis, most of Portela and Bangaeira were covered by lava in the period between 6 and 12 December 2014. Until 17 December 2014 the $\mathrm{W}$ lava lobe was propagating, but the settlement of Ilhéu de Losna was not yet harmed. Between 17 and 23 December 2014, this lava lobe advanced further towards the west, where it split into two $\mathrm{N}$ and $\mathrm{S}$ sublobes after reaching the Bordeira wall. At this point the third, smaller settlement of Ilhéu de Losna was destroyed. Since that time until the end of the eruption, the lava flow continued to thicken (e.g. we observe thickening of the active lava flow in January 2015, see Appendix C) but the lava flow extent stabilized, implying that effusive activity had slowed down. Only minor widening was observed at the W lava lobe between 23 and 28 December 2014. Also, during fieldwork, we observed an active surface flow on 12 January 2015 and minor propagation of the lava flow in between Monte Saia and Monte Beco. Details on the active surface flow are provided in Appendix C. Even though the eruption lasted until 8 February 2015, no lava flows were active in the last period of the eruption. The final boundary of the 2014-2015 lava flow as shown in black in Fig. 7 encloses an area of $4.85 \mathrm{~km}^{2}$. We provide the TerraSAR-X coherence maps in Appendix D. Therein the areas shown in blue have a low coherence because they were covered by lava. Other blue areas close to the vent and on the western flank of the Pico do Fogo stratocone are incoherent due to steep slopes, vent opening, and ash deposition.

\subsection{Topographic model}

We achieve a RMSE of $1.08 \mathrm{~m}$ for the global geolocation of our final posteruptive point cloud (cf. Table 1). This value was calculated using the Minuit minimization procedure between the final, combined point cloud and the pre-existing DEM. The error is smaller when comparing posteruptive and pre-eruptive grids at a $5 \mathrm{~m}$ pixel resolution $(\mathrm{RMSE}=0.89 \mathrm{~m})$. Moreover, when estimating this error only within the most representative area around the lava flow, as shown by the masks in Appendix B, the RMSE value decreases to $0.81 \mathrm{~m}$. However, after filling the remaining gaps, the overall RMSE between the filled DEM and the pre-existing DEM is $1.08 \mathrm{~m}$. With this accuracy, we provide 


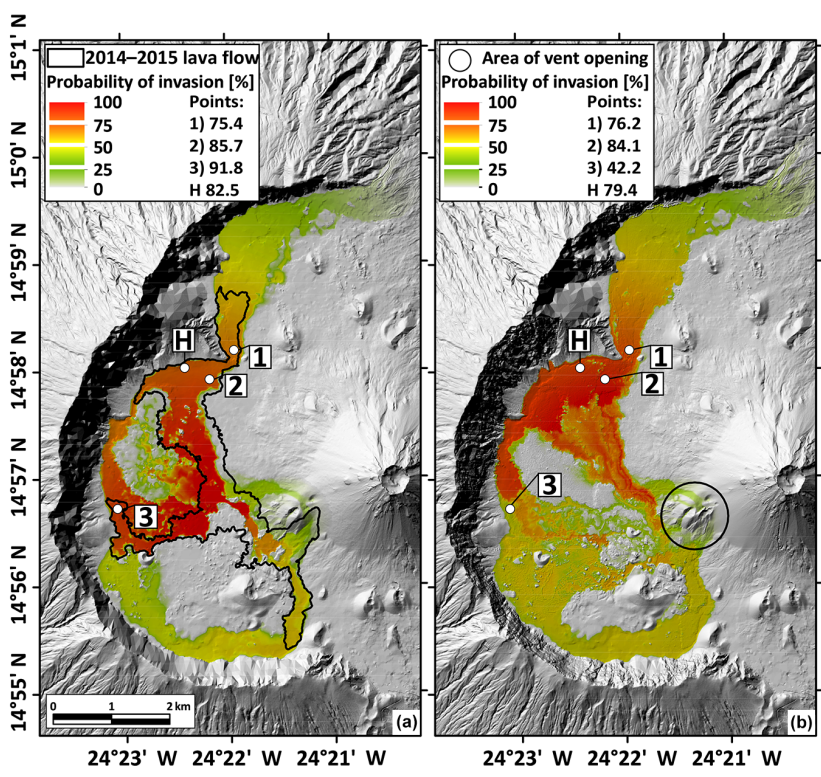

Figure 9. Pre- (a) and posteruptive (b) hazard maps for the Pico Pequeno scenario. No colour is 0 probability of invasion. Numbers of points correspond to the locations of the villages: (1) Bangaeira, (2) Portela, and (3) the settlement of Ilhéu de Losna. The letter " $H$ " marks the location of the new building which was constructed on the 2014-2015 lava flow.

a posteruptive DEM featuring a $5 \mathrm{~m}$ pixel resolution, which we consider updated to 16 January 2015.

The vertical difference between the pre- and posteruptive DEMs is a measure for lava flow characteristics, such as the lava flow thickness (Fig. 8b and c) and volume. The 20142015 lava flow has an average thickness of $8.9 \mathrm{~m}$. According to Fig. 8b and c, the 2014-2015 lava flow has a maximum thickness of $\sim 35 \mathrm{~m}$, but the cone at the eruption site built up to be maximally $52.7 \mathrm{~m}$. Negative thickness values are observed between the 1995 and 2014-2015 vents due to vent opening (up to $-12.8 \mathrm{~m}$ ) and along the edges of the lava flow due to loading (mostly less than $1 \mathrm{~m}$ of ground subsidence) (Fig. 8c). Lava flows are thicker where topography was filled by lava ponding. One very significant ponding area is located west of Portela (Fig. 8b, profiles A- $\mathrm{A}^{\prime}$ and $\mathrm{B}-\mathrm{A}^{\prime}$ ). Here, lava flows have a maximum thickness of $\sim 25 \mathrm{~m}$, while at the location of the villages, lava flows are maximally $8-9 \mathrm{~m}$ thick.

We calculate a total erupted lava volume of $43.2 \times 10^{6} \mathrm{~m}^{3}$, updated to 16 January 2015. From the RMSE between the pre- and posteruptive DEMs, we derive a maximum error in volume of $5.2 \times 10^{6} \mathrm{~m}^{3}$, corresponding to $11.9 \%$ of the total lava flow volume. Two additional error sources may lead to an underestimation of the total lava flow volume in our study. Firstly, data gaps still exist for an area of $46579 \mathrm{~m}^{2}$, or $\sim 1 \%$ of the area covered by the lava flow (dark red areas in Fig. 8b), introducing an error of about $1 \%$ to our lava flow volume estimate $\left(\sim 0.43 \times 10^{6} \mathrm{~m}^{3}\right)$. Secondly, we do not include any surface flows that were active after 16 Jan- uary 2015 (the acquisition date of scans MBC 4 and MBC 5 , cf. Table 1). However, we observed an active lava flow in the morning of 12 January 2015, which was still inflating after 17 January 2015, according to our multitemporal TLS analysis (described in Appendix C) and the TSX coherence mapping (cf. Sect. 4.1, Fig. 7, and Appendix D). We estimate the volume of the growing lava flow that is not covered by our data to roughly amount to $\sim 0.05 \times 10^{6} \mathrm{~m}^{3}$ (Appendix C). Therefore, our best total erupted volume estimate for the 2014-2015 flank eruption of Fogo Volcano is $43.7 \pm 5.2 \times 10^{6} \mathrm{~m}^{3}$.

\subsection{Simulation of the 2014-2015 lava flow}

The DOWNFLOW simulation output is a grid with the same cell size as the input DEM, where each pixel value gives the number of $N$ steepest descent paths that crossed the cell area. The highest $N$ values reflect the most likely paths followed by the lava downhill. However, this does not yet reflect a lava flow hazard, as the lava flow length is not constrained; i.e. all steepest descent paths run until they reach the end of the data set (Tarquini and Favalli, 2015).

The DOWNFLOW reconstruction of the 2014-2015 flow is given in Fig. 8a. The simulated lava flow covers $75 \%$ of the actual 2014-2015 lava flow area. We observe that single flows, i.e. flows that are not affected by multiple phases of emplacement (e.g. \#1, \#5, and \#4), are reproduced well by the DOWNFLOW simulation. However, lava flows that are emplaced in later effusive pulses are not as well represented (points \#6 and \#7). Pixels located within topographic ponds are hit by a simulation more often. In the area that was affected by the 1995 lava flow (in between the NW and W lava lobes of the 2014-2015 lava flow) the lava flow coverage is overestimated by the DOWNFLOW simulation.

\subsection{Lava flow hazard assessment}

\subsubsection{Lava flow hazard before the 2014-2015 eruption}

Our hazard maps show the probability of lava flow invasion, i.e. the likelihood that a future lava flow will inundate a specific pixel before the vent location is known. The preeruptive hazard maps are calculated on the basis of the preeruptive DEM that was acquired after the end of the 1995 eruption, but before the onset of the 2014-2015 eruption (on 23 November 2014).

Figure 9a shows the pre-eruptive hazard map for the Pico Pequeno scenario. We find that the locations of the villages (\#1, \#2, and \#3 in Fig. 9a) are zones of very high lava flow hazard (more than $75 \%$ ). By comparing the hazard map to the outline of the actual lava flow, we find that any vent opening within the given circle around Pico Pequeno would have resulted in approximately the same lava flow coverage as the 2014-2015 eruption. In fact, before the eruption, a small portion of the area that is now covered by lava flows even had 

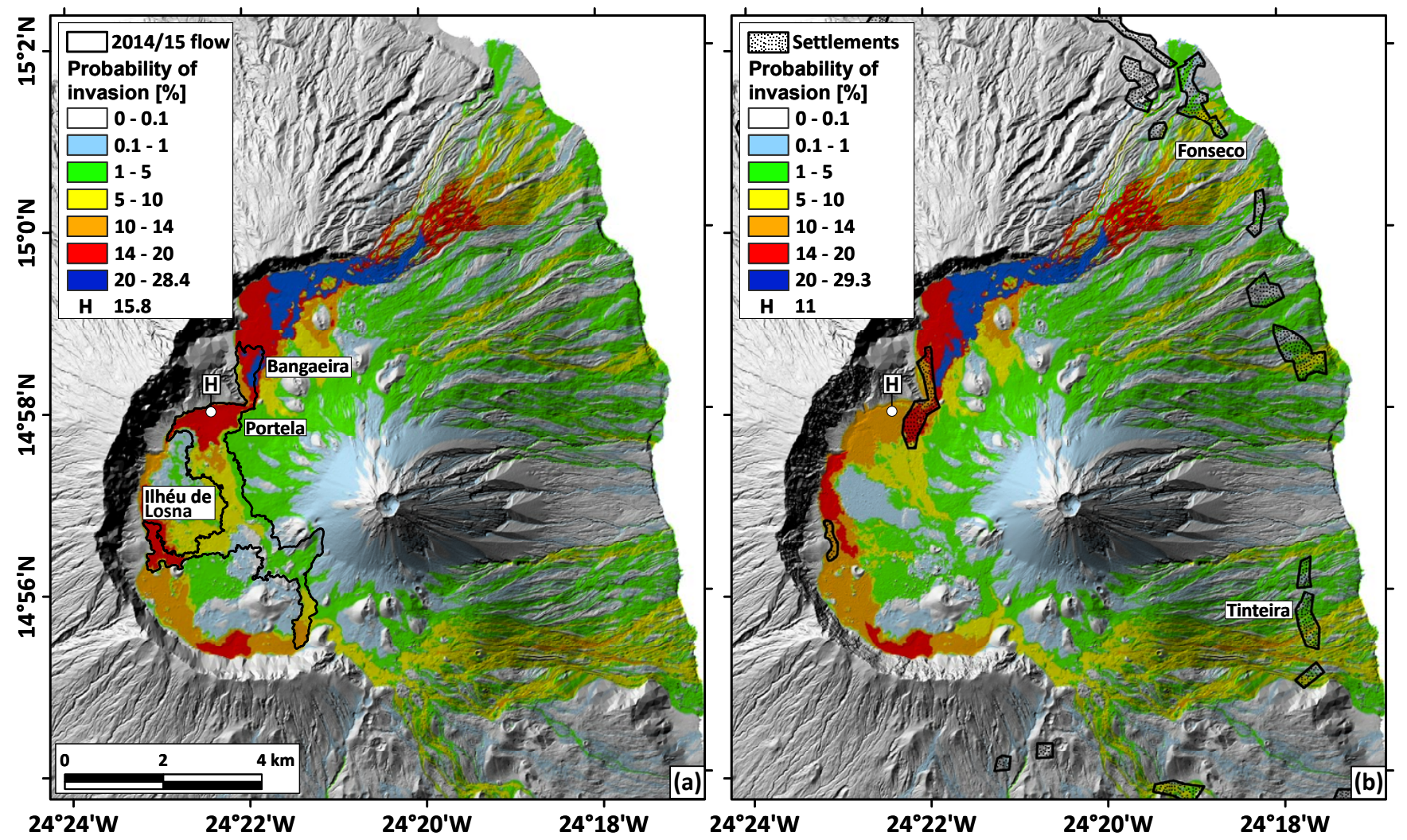

Figure 10. Pre- (a) and posteruptive (b) hazard maps for the Fogo scenario. The letter " $H$ " marks the location of the new building that was constructed on the 2014-2015 lava flow.

$100 \%$ probability of being invaded by a lava flow. On the other hand, areas that had $0 \%$ probability of invasion are now also covered with lava (Fig. 9a, cf. points 6 and 7 in Fig. 8a). At the same time, some parts of the area that is surrounded by the NW and W lava lobes, which is the area that is covered by the 1995 lava flow (Carracedo et al., 2015), were almost certain to be invaded according to this map, but were not affected by the 2014-2015 lava flow (Fig. 9a).

The pre-eruptive lava flow hazard map for the Fogo scenario is shown in Fig. 10a. Generally areas of high lava flow hazard cluster along the Bordeira wall, but low probability of lava flow invasion can be observed at the Pico do Fogo stratocone. Some of the larger cones within the Chã appear to serve as a barrier and produce a lava flow hazard shadow area behind them. This is especially true for Monte Beco, but also for the southern vent of the 1951 eruption and at the 1852 vent (Fig. 10a, for vent locations cf. Fig. 6). In this map, part of the area covered by the 1995 flow shows a probability of invasion of more than $7 \%$ (yellow areas outside the borders of the 2014-2015 lava flow). As for the volcano's eastern flank, comparably high lava flow hazard exists, especially along the edges of the landslide amphitheatre. Considering the fact that this map is not specific for vents around Pico Pequeno, it is striking that all three flow fronts of the 20142015 lava flow cover areas of increased or very high hazard
(10-28.4\%). The two villages of Portella and Bangaeira as well as the small settlement of Ilhéu de Losna were located in these high hazard zones of the NW and W lava lobes.

\subsubsection{Lava flow hazard after the 2014-2015 eruption}

We refer to this period as "posteruptive". The posteruptive hazard maps reveal the probability of lava flow invasion for the next eruption of Fogo Volcano.

The posteruptive hazard map for the Pico Pequeno scenario shows that the lava flow hazard is generally higher in the northern part of the Chã (Fig. 9b), with a maximum probability of lava flow invasion of $88.42 \%$. Especially closer to the vent (Pico Pequeno), channelling is not as strongly pronounced as before the 2014-2015 eruption (cf. Fig. 9a). The probability of lava flow invasion has not noticeably decreased for the locations of the villages of Portela (point \#2 in Fig. 9b) and Bangaeira (point \#1 in Fig. 9b), in fact, for the latter the lava flow hazard has even slightly increased. Only for the small settlement of Ilhéu de Losna (point \#3 in Fig. 9b), the probability of lava flow invasion has significantly decreased by $46 \%$. "Islands" of no lava flow hazard (probability of invasion $=0$ ) within the Chã exist on and behind Monte Beco, in an area west of Pico Pequeno, and also in areas south-east, north-east and directly north of Pico Pe- 
queno. According to the map, lava flows, if they were long enough, would flow to the north of the Chã from where they would continue to flow down the volcano's eastern flank.

The posteruptive lava flow hazard map for the Fogo scenario is shown in Fig. 10b and also available as supplementary material (Richter et al., 2016). According to this map, the probability of lava flow invasion during the next eruption of Fogo Volcano lies between 0 and $29.3 \%$, but $0 \%$ probability only occurs on top of cones or at some places along the Bordeira wall. The locations of the former towns of Portela and Bangaeira are still among the very high hazard zones and on the eastern flank of the volcano, other villages (e.g. Fonseco and Tinteira) are at risk.

The letter " $H$ " in Figs. 9 and 10 indicates the location of a new building that was constructed on top of the 2014-2015 lava flow (personal communication Mustafa Kerim Eren, November 2015), at $24.37360^{\circ} \mathrm{W}$ and $14.96744^{\circ} \mathrm{N}$. The lava flow at this point is $\sim 18 \mathrm{~m}$ thick. The lava flow hazard for the Pico Pequeno scenario at this location was $82.5 \%$ before and is $79.4 \%$ after the 2014-2015 eruption. The Fogo scenario hazard maps show a lava flow hazard for the location of the new building of $15.8 \%$ before and $11 \%$ after the eruption.

\subsubsection{Which future vent locations pose the highest risk to the villages of Portela and Bangaeira?}

To answer this question we provide the area of vent opening that, according to the DOWNFLOW simulation, could potentially result in a lava flow able to invade Portela and Bangaeira (Fig. 11). Such "catchment maps" are already widely used in other volcanic environments, such as at Mauna Loa, Hawai'i (e.g. Kauahikaua et al., 1995), Mount Etna, Italy (Favalli et al., 2009b), and Mount Cameroon, Cameroon (Favalli et al., 2011b). In Fig. 11, areas are ranked according to the minimum length that lava flows need to travel before reaching the village. In other words, it shows the area of future vent opening that potentially threaten Portela and Bangaeira (indicated by polygon) in colour. Any vent outside the coloured area lies downslope from the villages or belongs to a different catchment, and will therefore produce lava flows that will not harm the area covered by the polygon.

For example, if a future vent opens in the red/orange area, even short lava flows will reach the villages. On the other hand, if a future vent opens in the blue area, the lava flows need to travel a long distance before reaching the villages of Portela and Bangaeira. The length that a lava flow will have to reach before engulfing the villages is given in kilometres in Fig. 11. Technically, such a map can be provided for any pixel or area of interest on the basis of our Fogo DOWNFLOW simulation database.

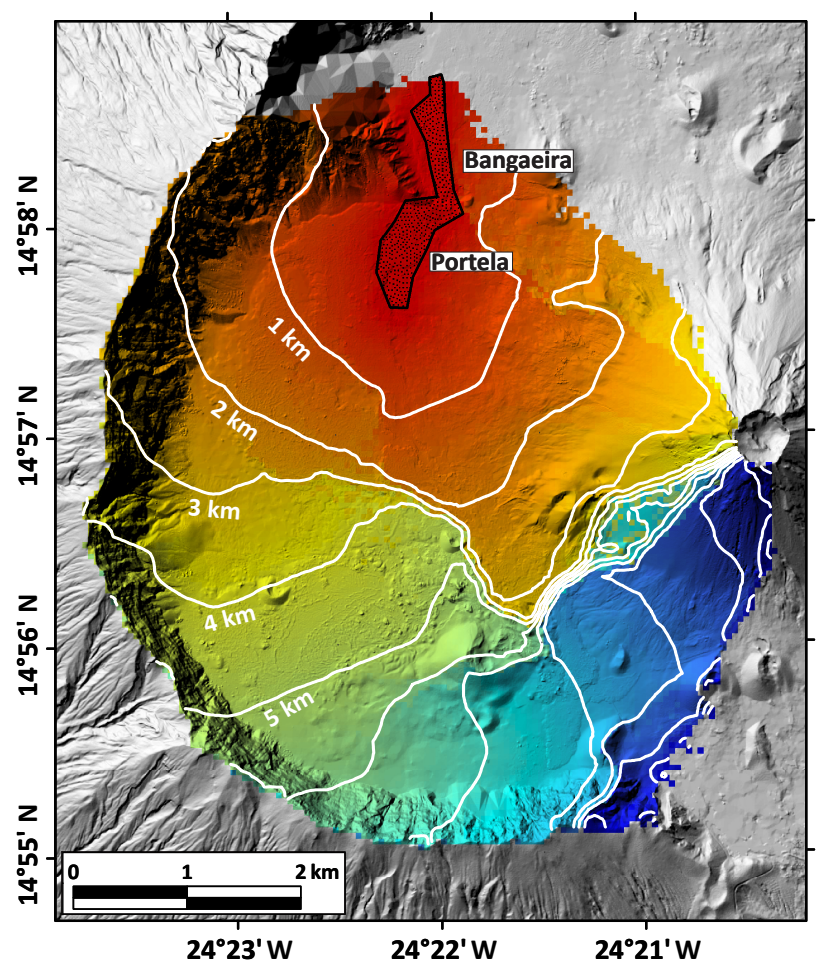

Figure 11. The coloured area shows all locations of future vents that will likely produce lava flows reaching and therefore affecting the villages of Portela and Bangaeira. Vents are herein ranked according to the minimum length that lava flows need to travel to reach the villages (black dotted polygon).

\section{Discussion}

The 2014-2015 eruption caused substantial damage on the island of Fogo. Approximately $90 \%$ of the houses in the villages of Portela and Bangaeira and the small agricultural settlement of Ilhéu de Losna as well as $24.6 \%$ of the farmlands within the Chã were destroyed by lava flows. This left approximately 1000 people homeless and seriously endangered their source of livelihood (United Nations, 2015). Because the volcano provides some of the most fertile soils on the island and facilitates geotourism, people are already returning to live in the Chã.

We are providing comprehensive lava flow hazard maps that are valid for the next eruption of Fogo Volcano. However, we did not investigate either vulnerability or preparedness. For hazard mitigation to be successful, it is of utmost importance to effectively communicate scientific results as well as the uncertainties related to lava flow hazards to the local emergency management authorities and decision makers (Kauahikaua and Tilling, 2014; Poland et al., 2016). 


\subsection{Lava flow mapping}

SAR coherence is known to be a valuable tool for defining lava flow boundaries (Zebker et al., 1996) and continues to be used for lava flow mapping purposes (e.g. Dietterich et al., 2012; Copernicus Emergency Management Service, 2014). A common disadvantage of this approach is that decorrelation may occur due to many factors besides lava flow emplacement, factors such as vent opening, vent growing, and ash deposition. We generate TSX coherence maps wherein we cannot delineate these eruptive processes apart in close proximity to the active vent at Pico Pequeno, causing our lava flow boundaries to be unprecise there (Appendix D). In other volcanic areas, vegetation and snow coverage will further limit the applicability of coherence maps to track flow emplacement (Dietterich et al., 2012), both of which are minimal or nonexistent at Fogo Volcano. Both the TSX coherence analysis and the vertical DEM difference give the same final 2014-2015 lava flow extent (cf. Fig. 7 and Appendix B), therefore, we are confident that our TSX data interpretation is sound.

\subsection{Posteruptive DEM generation and lava flow characteristics}

Depending on the instrument, TLS is capable of acquiring topographic data over distances of up to $\sim 6000 \mathrm{~m}$ (Riegl, 2013). However, previous studies have shown that, particularly in volcanic areas, useful point cloud densities could only be achieved at a maximum distance of $\sim 3500 \mathrm{~m}$ (James et al., 2009). Therefore, the technique is usually applied to study smaller areas of $\sim 1-5 \mathrm{~km}^{2}$ in very high spatial (centimetre scale) and temporal resolutions (up to 1 scan every $10 \mathrm{~min}$ ) (e.g. James et al., 2009; Jones et al., 2015; Slatcher et al., 2015).

Here we acquired a set of eight TLS scans to cover $\sim 75 \%$ of the Chã das Caldeiras, which is $\sim 35 \mathrm{~km}^{2}$ in size; another $\sim 1.75 \%$ of the area of the Chã is covered by our photogrammetric data. The main target of our survey was the area affected by the 2014-2015 lava flow, of which we covered $99 \%$ using combined TLS and photogrammetric data. The combination of SfM and TLS data has also been successfully applied in the past (e.g. Pesci et al., 2007). We are lacking data for two small gaps (dark red areas in Fig. 8b) and a small lava flow that was active during the period of our TLS data acquisition. To estimate the resulting error contribution of the active lava flow, we used a multitemporal TLS analysis (Appendix C).

The acquired TLS point cloud has an unprecedented resolution and quality, sufficient for the presented application, but the most critical remaining limitation of our TLS data set is the shadowing. In addition to minor shadows resulting from the viewing geometry, we have to mention one major shadow area at the north side of the 2014-2015 vent that had to be interpolated between the pre-existing and the posterup- tive DEMs. Due to the ongoing strombolian explosions during field work, the scanner could not be set up on the slopes of the Pico do Fogo cone, looking towards the west.

While the TLS data acquisition is time consuming and logistically challenging compared to the ground-based SfM technique, its precision is higher and the processing time is faster (Westoby et al., 2012). The general quality of our TLS data is better than that of our photogrammetric data, as camera images were acquired from locations along the upper ridge of the Bordeira wall at a rather large distance of $\sim 3-4 \mathrm{~km}$. Thus, our SfM data are affected by water vapour, the sunlight, and unclear skies due to volcanic gas and ash emissions. Therefore, we used TLS data where available and added SfM data only where needed.

The data and techniques used were designed to generate topographic information on the new lava flows; a survey to cover the whole island was not anticipated. For the study at hand we produced a DEM featuring a resolution of $5 \mathrm{~m}$ to meet the resolution of a pre-existing data set. On a more regional scale, where the point cloud is dense (e.g. at the active vent or at the buried villages of Portela and Bangaeira), our data can also be used at a much higher spatial resolution (centimetre scale).

From the vertical difference between pre- and posteruptive DEMs, we estimate a total erupted volume of $43.7 \pm 5.2 \times 10^{6} \mathrm{~m}^{3}$ for the 2014-2015 Fogo flow. When using this DEM difference method for lava flow volume calculations, errors in volume only occur due to the quality and the resolution of the DEMs (Albino et al., 2015). Albino et al. (2015) calculate a volume of $305.2 \pm 36.0 \times 10^{6} \mathrm{~m}^{3}$ for the 2011-2012 Nyamulagira lava flow based on TanDEM-X DEMs. The error estimated by Albino et al. (2015) corresponds to $11.8 \%$ of the total lava flow volume, which compares well with our error estimate (corresponding to $11.9 \%$ of the total lava flow volume). Therefore, the achieved DEM qualities are comparable; nevertheless our pre-eruptive DEM features a lower resolution and quality than our ground-based posteruptive DEM. Bagnardi et al. (2016) use TanDEM-X pre-eruptive topographic data and a posteruptive DEM calculated from tri-stereo Pleiades-1 satellite imagery to calculate a 2014-2015 Fogo flow volume of $45.84 \pm 0.02 \times 10^{6} \mathrm{~m}^{3}$. In this case both DEM data sets are of high quality and resolution, therefore (in contrast to our estimation) the uncertainty of the volume calculation was derived by using the relation for uncorrelated errors provided by Favalli et al. (2010) (also used by Poland, 2014). Results by Bagnardi et al. (2016) imply that we underestimate the lava flow volume by only $2.12-2.16 \times 10^{6} \mathrm{~m}^{3}$ (i.e. less than $5 \%$ of our total lava flow volume). However, this comparison neglects any changes in volume between 16 January 2015 and 20 June 2015 due to lava flow inflation upon emplacement or subsequent cooling and subsidence.

The DEM difference method used here gives a total erupted bulk volume. Assuming a $25 \%$ vesicularity, as often used in literature (e.g. Wolfe et al., 1987; Poland, 2014; 
Bagnardi et al., 2016), the dense-rock equivalent (DRE) value is $\sim 33 \times 10^{6} \mathrm{~m}^{3}$. Our DRE volume estimate compares well with the value given by Bagnardi et al. (2016) $\left(\sim 34.37 \pm 0.02 \times 10^{6} \mathrm{~m}^{3}\right)$ but is three times larger than previous estimations by Ferrucci et al. (2015). Cappello et al. (2016) calculated a total, DRE lava flow volume of $15 \times 10^{6} \mathrm{~m}^{3}$ from time-averaged discharge rates as inferred from HOTSAT satellite data, which, according to our results, also underestimates the 2014-2015 lava flow volume. The reasons for this disagreement need to be addressed in future studies as lava vesicularity alone cannot fully explain this difference. We calculate a mean output rate (MOR) throughout the 2014-2015 Fogo eruption of $\sim 6.5 \mathrm{~m}^{3} \mathrm{~s}^{-1}$ $\left(M_{\mathrm{DORE}}=4.9 \mathrm{~m}^{3} \mathrm{~s}^{-1}\right)$ by dividing our total erupted lava flow volume $\left(43.7 \times 10^{6} \mathrm{~m}^{3}\right)$ by the duration of the eruption (78 days $\times 86400$ s) (e.g. Harris et al., 2007; Harris and Rowland, 2009). However, during the early phase of the eruption the time-averaged discharge rate (TADR) was considerably higher with peaks of 24-27 $\mathrm{m}^{3} \mathrm{~s}^{-1}$ (Cappello et al., 2016). According to our results, the 2014-2015 lava flow has a very similar surface coverage $\left(4.85 \mathrm{~km}^{2}\right)$ and volume $\left(43.7 \pm 5.2 \times 10^{6} \mathrm{~m}^{3}\right)$ to the lava flow of the 1995 eruption (area: $\sim 4.7 \mathrm{~km}^{2}$, volume: $\sim 46 \times 10^{6} \mathrm{~m}^{3}$ ), which lasted 55 days (MOR $\sim 9.7 \mathrm{~m}^{3} \mathrm{~s}^{-1}$ ) (Amelung and Day, 2002).

\subsection{DOWNFLOW performance}

Using the DOWNFLOW algorithm to simulate the final 2014-2015 lava flow coverage we achieve a maximum fit of $\mu=0.47$ without applying a lava flow length constraint. This is a very good result, considering the fact that at Mount Etna, where very high-quality DEMs are available and a purely gravity driven model is expected to perform well due to lava flow emplacement on steep slopes, fitness values range between 0.35 and 0.69 (Tarquini and Favalli, 2011). The greatest strength of our probabilistic approach is its simplicity. Once the DOWNFLOW model parameter $\Delta h$ is calibrated for a certain volcano, only the topography and the vent position is needed to run a simulation. Cappello et al. (2016) used the MAGFLOW physical model to estimate the lava flow hazard in near real time during the ongoing 2014-2015 Fogo eruption. The authors used effusion rate estimates and vent location coordinates from the HOTSAT satellite thermal monitoring system to simulate the temporal and spatial evolution of the lava flow field, which we cannot resolve using a probabilistic approach. Cappello et al. (2016) were able to reach a maximum fit of 0.7 . On the downside, a physical model requires knowledge of a number of parameters, such as the temperature-dependent rheological characteristics and the temporal variation of the effusion rate, in addition to the vent location and the topography. These parameters are usually very difficult to measure; for example, the integrated effusion rate provided by Cappello et al. (2016) gives the DRE volume of $15 \times 10^{6} \mathrm{~m}^{3}$ which, according to our DEM difference derived DRE volume, is an underestimation of $\sim 100 \%$.
DOWNFLOW is known to work well on steep terrain (Favalli et al., 2009a, 2011b; Tarquini and Favalli, 2011). In this study the DOWNFLOW simulation has proved to perform well on rather flat areas like the Chã das Caldeiras. This implies that lava flow paths are largely controlled by the topography even, and maybe especially, in relatively flat terrain. In order to discuss the DOWNFLOW performance, we compare the simulation (Fig. 8a) to the real lava flow coverage (Figs. 7, 8b). The very early phase of the 20142015 eruption, when lava travelled in a well-defined channel (Fig. 7; Fig. 8b, profile $\mathrm{C}_{-} \mathrm{C}^{\prime}$ ), is reproduced by the DOWNFLOW simulation in great accuracy (Fig. 8a), but the final width of the lava flow is underestimated locally (e.g. at points \#6 and \#7 in Fig. 8a). As lava flows create their own topography, this is a result of the changing topographic conditions during the eruption, rather than a limitation of the simulation. As long as the simulation does not run into a local minimum, only random perturbation, no filling is applied along the path (cf. Sect. 3.3). Therefore, channels are increasingly difficult to overflow, the deeper they are relative to $\Delta h$ (here $\Delta h=3 \mathrm{~m}$ ). Profile $\mathrm{C}-\mathrm{C}^{\prime}$ in Fig. $8 \mathrm{~b}$ shows that the channel in the 2014-2015 Fogo case was $\sim 10 \mathrm{~m}$ deep and $\sim 80 \mathrm{~m}$ wide, and therefore forced all steepest descent paths into a bundle. Furthermore, it seems that lava flows are thicker where the number of paths crossing a pixel in the simulation are highest (e.g. \#2, \#3, \#4, and across profile $\mathrm{C}-\mathrm{C}^{\prime}$ in Fig. 8b). This applies especially to topographic ponds (profiles $\mathrm{A}-\mathrm{A}^{\prime}$ and $\mathrm{B}-\mathrm{A}^{\prime}$ in Fig. 8b). Also this can be explained by the DOWNFLOW filling algorithm, as topographic ponds (if deep enough) represent a local minimum, which causes the lava flow simulation to fill in the local topography before continuing the path downslope. The existence of this well-pronounced ponding area (cf. thickness map and the DOWNFLOW simulation in Fig. 8) explains the fact that, even though the lava flow had reached the first houses of Portela within the first days of the eruption, it stopped for a couple of days, while ponding, before continuing its path downslope, overflowing the villages of Portela and Bangaeira (Fig. 7, Sect. 4.1).

In summary, differences between the simulation and the real lava flow coverage occur due to two main facts: first, the DOWNFLOW simulation runs until the lava flows hit the end of the DEM, while the actual lava flows stop when effusive activity ceases. Second, the DOWNFLOW simulation (of $N=10000$ runs) starts only once at the vent location, then keeps running downslope on the initial (but perturbed) topography, while the real lava flow is produced iteratively depending on the supply rate at the vent. From the above discussion, we conclude that both channelling and ponding can be very well simulated by the DOWNFLOW code. Furthermore, we consider the failure of exactly forecasting the final 2014-2015 lava flow coverage to reflect the changing topographic conditions, rather than a limitation of the capability or performance of the DOWNFLOW simulation. We therefore suggest that iterative updates of the topographic model, 
maybe even during an ongoing eruptive crisis, are important for accounting for the changing conditions when forecasting paths of lava flows using the DOWNFLOW code.

\subsection{Lava flow hazard maps}

Our volcano-wide hazard maps (Fig. 10a and b) allow speculations about infilling mechanisms of giant landslide amphitheatres of volcanic origin. We find that high lava flow hazard areas are located mainly along the wall of the landslide scarp. Flows are then likely to follow pathways down the flanks, along the edges of the scarp. Depending on the probability distribution of vent opening, we would expect generally similar main lava flow hazard patterns for other ocean islands with infilling landslide amphitheatres and comparable topographic structure, such as Piton de la Fournaise (La Réunion, France) or Teide Volcano (Tenerife, Spain).

However, regarding the lava flow hazard estimation, we are left with uncertainties. The DOWNFLOW hazard map generation depends on the topography, $\Delta h$, the PDF of vent opening, and the lava flow length constraint. With our new posteruptive DEM, we have a very reliable data set for the DOWNFLOW simulation at a resolution that meets or even exceeds the requirements of the model. The parameter $\Delta h$ has a wide range of fit (between $<2.5 \mathrm{~m}$ and $>4 \mathrm{~m}$ ) according to the calibration (Sect. 3.3, Fig. 4), meaning that the parameter $\Delta h$ is not among the main sources of error. Previous studies have shown that the tuning of the parameters $\Delta h$ and $N$ gives a better fit, when different lava flows of one volcano are taken into account (Tarquini and Favalli, 2015). However, it has also been observed that DOWNFLOW can be successfully calibrated for less well-studied volcanoes and that $\Delta h$ varies between different volcanoes, but is robust (once wellcalibrated) for different lava flows of one volcano (Favalli et al., 2011b, 2012; Tarquini and Favalli, 2011). As for the PDF, previous studies have shown that even with a low number of vents, the resulting vent distribution is robust (Tarquini and Favalli, 2013). However, as obvious from the PDF of vent opening (Fig. 6), Pico Pequeno (i.e. the location of both the 1995 and 2014-2015 vents), is not located in the zones of highest probability of vent opening. To account for this, we provide a dedicated Pico Pequeno scenario. But this also highlights the importance of knowledge about likely future vent locations for lava flow hazard assessment in general. In contrast, the lava flow lengths constraint is known as a potential source for large errors (Tarquini and Favalli, 2013). A direct correlation between effusion rate and lava flow length was found by Walker et al. (1973). Considering the MOR and MOR ${ }_{\text {DRE }}$ calculated above (Sect. 5.2), the minimum and maximum lava flow lengths of the 2014-2015 eruption are $\sim 2$ and $\sim 10 \mathrm{~km}$ respectively, which roughly agree with the limits of our lava flow length constraint (min. $3 \mathrm{~km}$ and max. $9 \mathrm{~km}$ ). In our Fogo case study the historic record is sparse, which causes the lava flow length constraint to be poorly defined. Overestimating the lava flow length would produce hazard maps with high hazard zones smeared or extended downhill. Underestimating the lava flow length produces hazard maps with high hazard zones that shrink uphill. To minimize the introduced error, we take into account a rather large range of possible flow lengths.

Future studies are needed to address the question why very similar subsurface pathways were reused and adjacent dikes developed during the 1995 and 2014-2015 eruptions (Amelung and Day, 2002; González et al., 2015). Therefore, we do not state that a future vent will open within the circle that is shown in Figs. 6 and 9b, at approximately the same location as during the two most recent eruptions. Rather we provide a hazard map for this scenario because at this point of time and knowledge, we cannot ignore the possibility that a future vent will be located there. In the same way that the preeruptive hazard maps would have been useful in forecasting the 2014-2015 lava flow paths, the posteruptive hazard maps are valid for the next eruption of Fogo Volcano. Now that we know the exact location of the 2014-2015 vent, we can state that the pre-eruptive hazard map for the Pico Pequeno scenario (Fig. 9a) predicts the lava flow path of this eruption with a high level of confidence. This is especially true for the early phase of the eruption. Therefore, this map can be treated as a forecast of the 2014-2015 lava flow path. However, the above discussed limitations related to the modified topography during an eruption (Sect. 5.3) also result in uncertainties in our lava flow hazard maps, e.g. areas with $0 \%$ probability of invasion are now covered with lava while other areas that were $100 \%$ certain to be invaded are not covered by the 2014-2015 lava flow (Fig. 9a, Sect. 4.4.1). However, our results suggest that if the next eruption occurs at Pico Pequeno, the initial lava flow path will most likely be the one provided by the posteruptive Pico Pequeno hazard map (Fig. 9b).

When comparing the pre- (Figs. 9a and 10a) and the posteruptive hazard maps (Figs. 9b and 10b), the 2014-2015 eruption changed the local lava flow hazard significantly at areas that are now covered by the 2014-2015 lava flow (general decrease) and along its edges (general increase). The risk for the village of Portela has not changed significantly in terms of the maximum probability of lava flow invasion ( $89 \%$, both before and after the 2014-2015 eruption). However, the distribution of hazard has changed. Within the town, the highest probability now exists for the parts of Portela that had low probabilities before the eruption and were also not covered by the lava flows (especially obvious in Fig. 10a and b). The hypothesis that lavas are unlikely to inundate areas that were previously overflowed is a common assumption at Fogo (personal communication with residents). The new building (indicated by letter " $\mathrm{H}$ " in Figs. 9 and 10) is located where the 2014-2015 lava flow is about twice as thick as the average 2014-2015 flow thickness. Nevertheless, in this area the lava flow hazard remains high (Figs. 9 and 10, Sect. 4.4.2). 
Our results (Figs. 9 and 10) also show that the village of Bangaeira is just as prone to be invaded by future lava flows as before the 2014-2015 eruption. Therefore, the assumption that previously overflowed areas are now safe and will not be overrun during the next eruption cannot be confirmed for this region either. The only chances for the villages to remain untroubled would be either to have an eruption from a vent outside the catchment (Fig. 11), or a vent inside the catchment but producing shorter lava flows as compared to the previously observed cases, or that early effusive pulses update the local topography in a way that our hazard maps are no longer valid.

Of the inhabited areas within the Chã, solely Ilhéu de Losna shows a significant decrease (46\%) in lava flow hazard. That said, probability values out of range of the statistics are always possible, meaning that the next lava flow might also affect areas with very low probability.

\section{Conclusion}

The 2014-2015 Fogo eruption ended on 8 February 2015 after 78 days of activity; meanwhile three prominent villages were destroyed by lava flows. Satellite radar observations allowed time-dependent mapping of the lava flow evolution during the 2014-2015 eruptive crisis of Fogo Volcano. Furthermore, we used combined TLS and photogrammetric data to quantify the thickness of the lava flows. We observed a maximum lava flow thickness of $\sim 35 \mathrm{~m}$ close to the vent; a remarkable thickness of up to $\sim 25 \mathrm{~m}$ was observed approximately $4 \mathrm{~km}$ away from the vent in a ponding area west of the village of Portela. We estimate a total erupted lava volume of $43.7 \pm 5.2 \times 10^{6} \mathrm{~m}^{3}$ by comparing pre- and posteruptive topographies. According to our results, this eruption was comparable in volume, covered area, and source location to the 1995 eruption.
Based on thousands of lava flow simulations, we produced lava flow hazard maps for Fogo Volcano. Provided that these are communicated to decision makers and major investments in education are made, our results can be considered when planning new infrastructure and the resettlement of the villages. The maps were produced using the DOWNFLOW stochastic model (Favalli et al., 2005) on the basis of our high-resolution topographic map. Results of our lava flow hazard analysis imply that the two main villages within the Chã, Portela, and Bangaeira, remain at high risk. Even the area west of Portela, where the topographic relief was partially infilled with a lava flow of up to $\sim 25 \mathrm{~m}$ thickness, is likely to be invaded again during a future eruption. These findings imply that an area once covered by a lava flow may again be overrun in the following eruption, at Fogo Volcano and elsewhere in the world. We also show which area of future vent opening will likely produce lava flows reaching and therefore affecting two villages (Fig. 11). The lava flow hazard at the location of Ilhéu de Losna, however, has significantly decreased. Our study highlights the need for updating lava flow hazard maps shortly after eruptions in order to quantify the changes in lava flow lines. Updated topographic data sets are a key parameter for lava flow hazard assessments at volcanoes in general.

\section{Data availability}

We provide the posteruptive combined TLS and photogrammetric DEM in geotiff-format in the Supplement of this publication. We also deliver our hazard maps, the thickness map of the 2014-2015 lava flow, the catchment map, and shaded reliefs of the pre-eruptive, posteruptive, and TLS DEMs in $\mathrm{kml}$ format in the Supplement. Furthermore, the post-2015 lava flow hazard for Fogo Volcano, Cabo Verde is provided in map format by Richter et al. (2016). 


\section{Appendix A: Field observations}

During our field work between 11 January 2015 and 21 January 2015, Pico Pequeno displayed three different phases of activity. (1) Mild degassing from the vent, sometimes in combination with lava flows from the mount SW of Pico Pequeno (cf. Fig. C1), accompanied by minor ash puffs without much explosive activity and no audible sounds. This activity was observed several early mornings. (2) Distinct ash puffs every 0.5 to $5 \mathrm{~min}$ of up to $700 \mathrm{~m}$ height. These explosions emit bombs which mostly fall back into the vent. A sloshing sound can be heard from the lava within the conduit and explosions are sometimes so loud that an echo from the Bordeira can be heard. This activity was mostly observed in the afternoon. (3) Intense explosive activity, almost continuous high lava fountains (up to $300 \mathrm{~m}$ ) occurred well above the crater rim. Explosions eject bombs up to $700 \mathrm{~m}$, impacting half way up Pico and two-thirds down Pico Pequeno. Ash explosions rose up to $1000 \mathrm{~m}$, were then drifting above Pico and raining out mostly on its flanks. Intense, almost constant noise, with many echoes from the Bordeira was audible. This activity was observed on 4 different days around sunset (18:30 to 19:00 LT, UTC -01:00). 
Appendix B: Masks

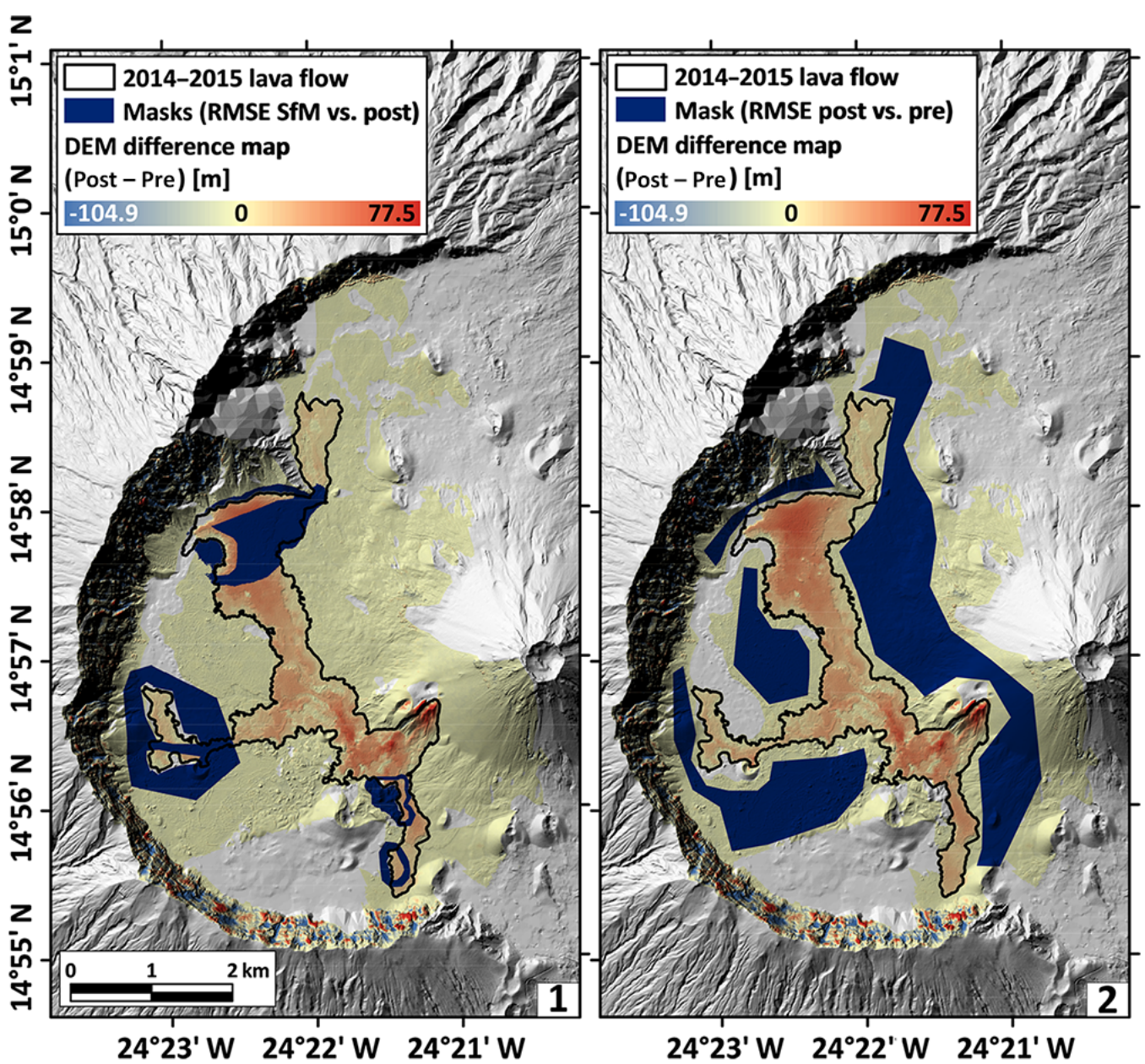

Figure B1. Minuit RMSEs (1) in the blue regions from top to bottom (SfM DEMs vs. posteruptive DEM) at $0.75 \mathrm{~m}, 1.45 \mathrm{~m}, 1.79 \mathrm{~m}, 0.69 \mathrm{~m}$ and (2) in a buffer area outside the lava flow (post- vs. pre-eruptive topography): $0.81 \mathrm{~m}$ (overall). 


\section{Appendix C: Multitemporal TLS analysis}

A small lava flow was still active during our field work on 12 January 2015. In order to map possible changes in the flow field, including active lava flows, the set-up on Monte Saia was kept the same over the duration of our field campaign, i.e. six reflectors and the scanner tripod were permanently installed (see Fig. C1). From this position (see scanner position in Fig. $\mathrm{C} 1$ and SAIA1 in Table C) we acquired three multitemporal, very high-resolution $360^{\circ}$ scans (on 12, 17 and 21 January 2015 respectively). Details on the tie point registration and Minuit minimization results of these three scans are listed in Table C1.

Only the first of these scans was used in combination with the Beco and Amarelo scans to produce the updated DEM (due to slightly worse weather conditions on the other days). Therefore, the active lava flow is not completely included in our posteruptive DEM, which is only updated until 16 January 2015 (the acquisition date of scans MBC 4 and MBC 5, cf. Table 1). Even though the TLS points acquired on 17 January 2015 and 21 January 2015 were too sparse to create a DEM (cf. No. of points in Table C), they were dense enough for estimating the flow volume to roughly amount to $0.15 \times 10^{6} \mathrm{~m}^{3}$ (from the vertical difference between SAIA3 and SAIA1, cf. Fig. C1) and $0.05 \times 10^{6} \mathrm{~m}^{3}$ (from the vertical difference between SAIA3 and SAIA2, cf. Fig. C2). 

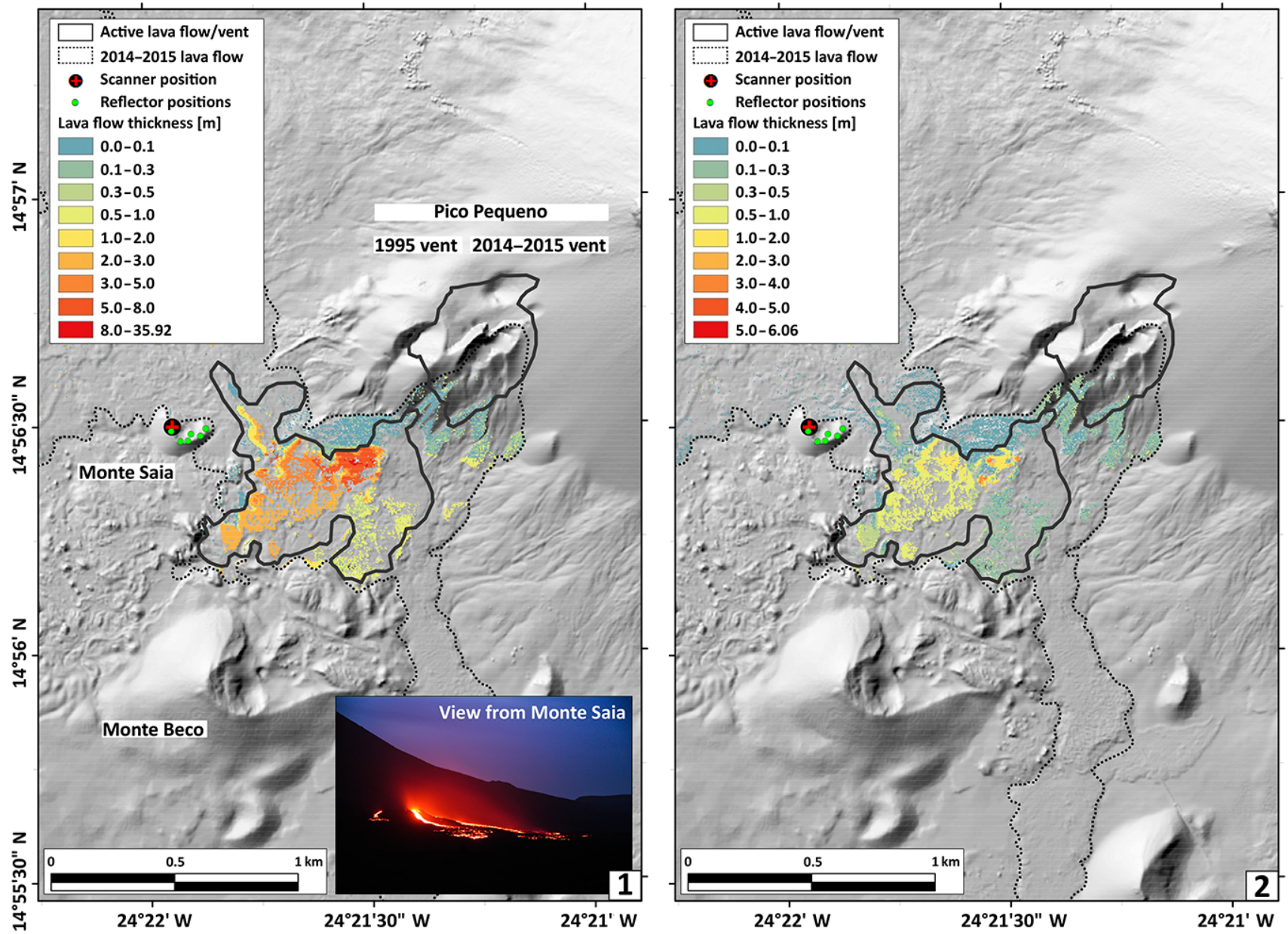

Figure C1. Thickness maps of the active lava flow calculated from the vertical difference between the TLS data acquired on 21 January 2015 minus (1) the TLS data acquired on 12 January 2015 and (2) the TLS data acquired on 17 January 2015 (all in grid format). Outlines of the lava flows are taken from TerraSAR-X coherence (Sects. 3.1, 4.1, 5.1, Fig. 7, and Appendix D). Inset shows a photograph taken in the early morning of 12 January 2015 from a position on Monte Saia, looking south-east.

Table C1. GPS coordinates of scanner position and point cloud accuracies of the multitemporal TLS data acquired from Monte Saia.

\begin{tabular}{|c|c|c|c|c|c|c|c|c|c|c|c|c|c|c|}
\hline \multirow[t]{2}{*}{ Scan name } & \multicolumn{6}{|c|}{ Scanner location (GPS) } & \multirow[t]{2}{*}{ Date } & \multirow{2}{*}{$\begin{array}{l}\text { Local } \\
\text { time }\end{array}$} & \multirow[t]{2}{*}{ No. of points } & \multirow{2}{*}{$\begin{array}{c}\text { No. of points } \\
\text { (filtered, cleaned) }\end{array}$} & \multicolumn{2}{|c|}{$\begin{array}{c}\text { Tie point } \\
\text { registration }\end{array}$} & \multicolumn{2}{|l|}{ Minuit } \\
\hline & Lat & Lat error & Long & Long error & $\mathrm{H}$ & H error & & & & & No. of tie points & $\mathrm{SD}[\mathrm{m}]$ & No. of points (used) & RMSE [m] \\
\hline SAIA1 & N $14^{\circ} 56^{\prime} 29.86298^{\prime \prime}$ & 0.003 & W $24^{\circ} 21^{\prime} 56.92498^{\prime \prime}$ & 0.003 & 1856.169 & 0.008 & 12.01 .2015 & $09: 45$ & 98068086 & 20027376 & 6 & 0.0064 & 6921595 & 1.320337 \\
\hline SAIA2 & & & & & & & 17.01 .2015 & $20: 30$ & 55767098 & 13325875 & 6 & 0.0033 & 4712745 & 1.251083 \\
\hline SAIA3 & & & & & & & 21.01 .2015 & 11:05 & 54885049 & 11611177 & 6 & 0.0048 & 3943593 & 1.266489 \\
\hline
\end{tabular}


Appendix D: Appendix D - TerraSAR-X coherence maps
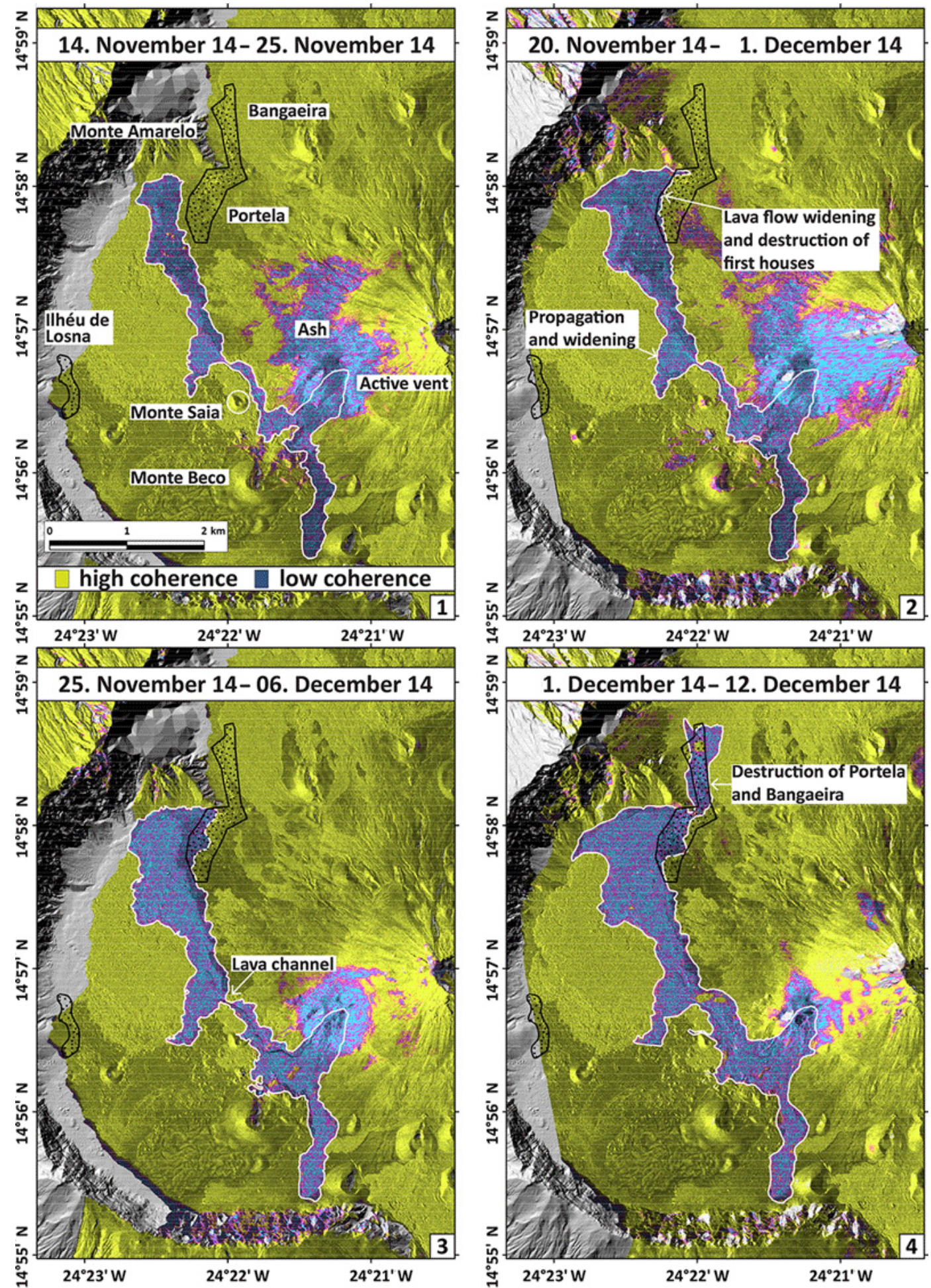

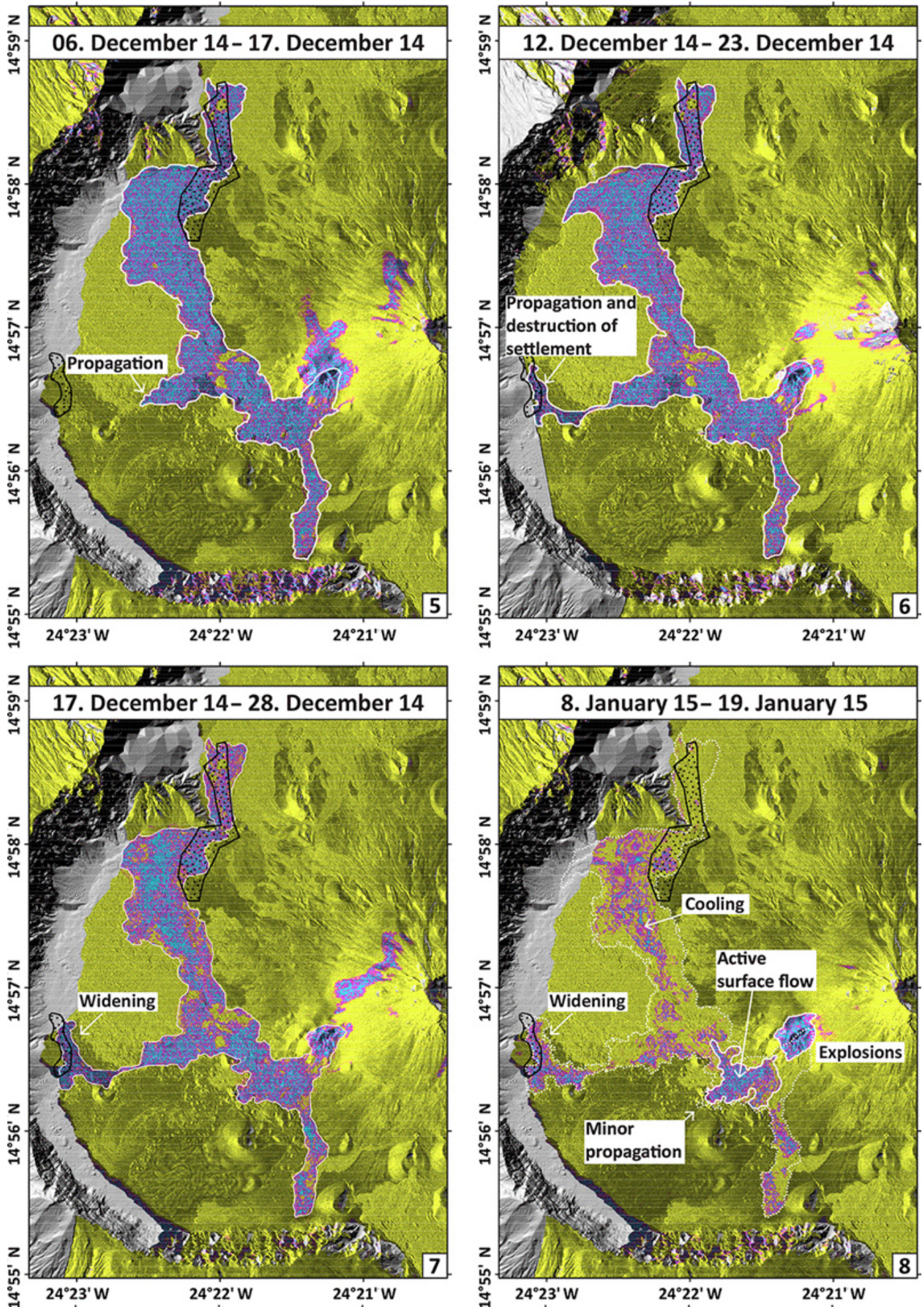

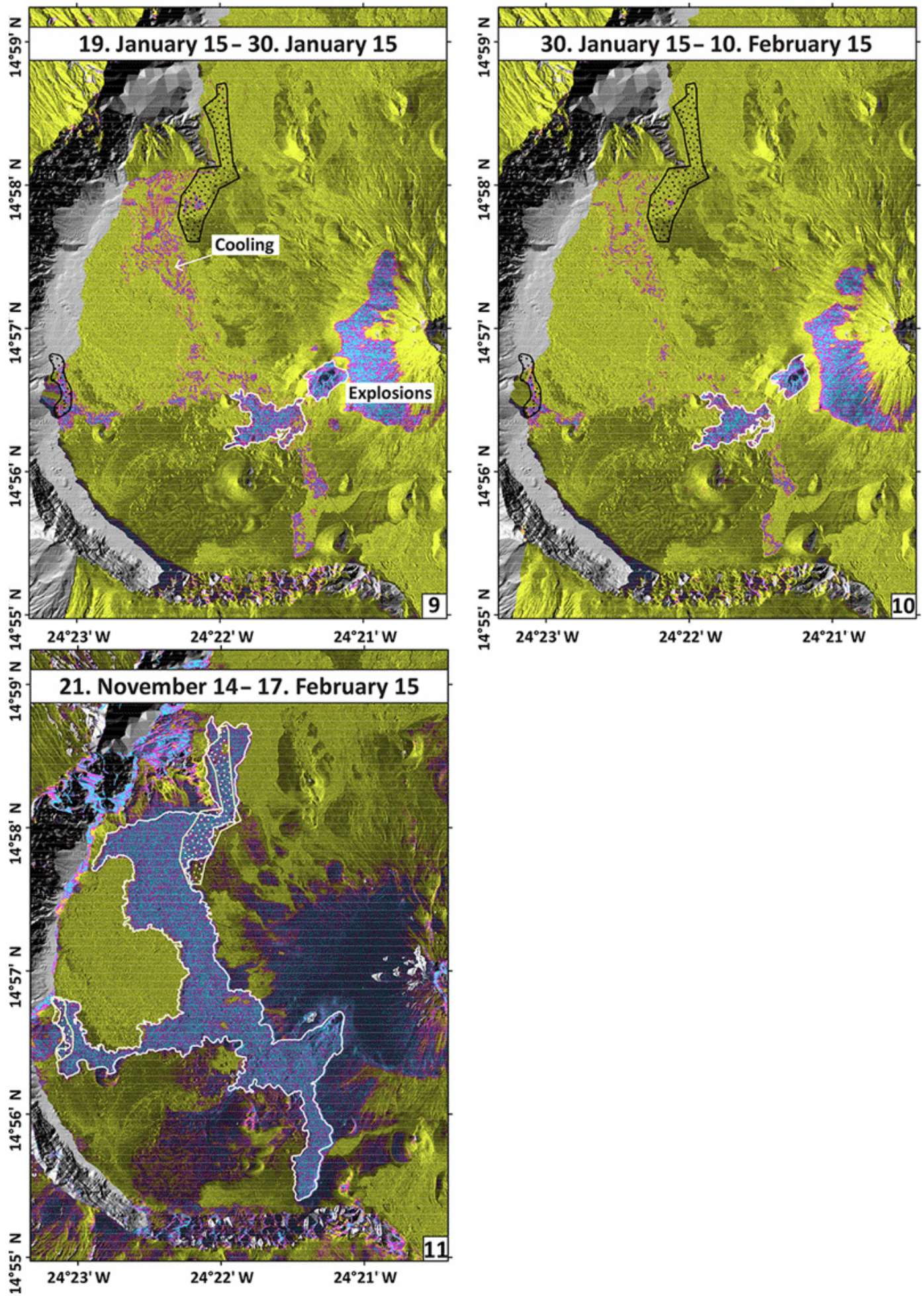


\section{The Supplement related to this article is available online at doi:10.5194/nhess-16-1925-2016-supplement.}

Author contributions. Nicole Richter, Elske de Zeeuw-van Dalfsen, and Judith Levy carried out the field work. Sónia Silva Victória provided assistance in the field and contributed photographs. Nicole Richter processed the TerraSAR-X data. Massimiliano Favalli developed the DOWNFLOW model and code. Massimiliano Favalli and Nicole Richter performed the TLS and SfM data processing and model simulations. Rui Manuel da Silva Fernandes processed the GPS data. Thomas R. Walter supervised the study. Thomas R. Walter and Alessandro Fornaciai helped with the photogrammetric data processing. Nemesio M. Pérez provided the preeruptive DEM. Nicole Richter prepared the manuscript with contributions from all coauthors.

Acknowledgements. This work was supported by the Helmholtz Alliance Remote Sensing and Earth System Dynamics (HGF EDA). Field work was funded by the GFZ Hazard and Risk Team (HART) program. Access to the Riegl instrument was kindly provided by Niels Hovius. Operating instructions were given by Kristen Cook. The TerraSAR-X data were provided by the German Aerospace Center (DLR) through the proposal ID 1505. The C4G monitoring campaign was made possible through an emergency financial support provided by FCT (Fundação para a Ciência e Tecnologia), Portugal. FCT also funded the GPS data processing in the framework of the FIRE (PTDC/GEO-GEO/1123/2014) project. We are grateful to Eleonora Rivalta, Jacqueline Salzer and Adam Mehlhorn, whose valuable suggestions helped to improve the manuscript. We especially thank Michael Poland, Matthieu Kervyn, and Sónia Calvari for detailed and constructive reviews that greatly improved the manuscript. We also thank Paulo Fernandes Teixeira and Lourenco Francisco Fernandes for their invaluable assistance during fieldwork on Fogo Island.

The article processing charges for this open-access

publication were covered by a Research

Centre of the Helmholtz Association.

Edited by: O. Katz

Reviewed by: M. P. Poland, M. Kervyn, and S. Calvari

\section{References}

Albino, F., Smets, B., Oreye, N., and Kervyn, F.: High-resolution TanDEM-X DEM: An accurate method to estimate lava flow volumes at Nyamulagira Volcano (D. R. Congo), J. Geophys. Res.Earth, 120, 4189-4207, doi:10.1002/2015JB011988, 2015.

Altamimi, Z., Collilieux, X., and Métivier, L.: An improved solution of the international terrestrial reference frame, J. Geodyn., 85, 457-473, doi:10.1007/s00190-011-0444-4, 2011.

Amelung, F. and Day, S. J.: InSAR observations of the 1995 Fogo, Cape Verde, eruption: Implications for the effects of collapse events upon island volcanoes, Geophys. Res. Lett., 29, 5-8, doi:10.1029/2001GL013760, 2002.
Bagnardi, M., González, P. J., and Hooper, A.: High-resolution digital elevation model from tri-stereo Pleiades-1 satellite imagery for lava flow volume estimates at Fogo Volcano, Geophys. Res. Lett., 43, 6267-6275, doi:10.1002/2016GL069457, 2016.

Bartolini, S., Cappello, A., Martí, J., and Del Negro, C.: QVAST: a new Quantum GIS plugin for estimating volcanic susceptibility, Nat. Hazards Earth Syst. Sci., 13, 3031-3042, doi:10.5194/nhess-13-3031-2013, 2013.

Bowman, A. W. and Azzalini, A.: Computational aspects of nonparametric smoothing with illustrations from the sm library, Comput. Stat. Data Anal., 42, 545-560, doi:10.1016/S01679473(02)00118-4, 2003.

Cappello, A., Herault, A., Bilotta, G., Ganci, G., and Del Negro, C.: MAGFLOW: a physics-based model for the dynamics of lavaflow emplacement, in: Detecting, Modelling and Responding to Effusive Eruptions, Spec. Publ. 426, edited by: Harris, A. J. L., De Groeve, T., Garel, F., and Carn, S. A., Geological Society, London, UK, doi:10.1144/SP426.16, 2015.

Cappello, A., Ganci, G., Calvari, S., Pérez, N. M., Hernández, P. A., Silva, S. V., Cabral, J., and Del Negro, C.: Lava flow hazard modeling during the 2014-2015 Fogo eruption, Cape Verde, J. Geophys. Res.-Earth, 121, 1-14, doi:10.1002/2015JB012666, 2016.

Carracedo, J.-C., Perez-Torrado, F. J., Rodriguez-Gonzalez, A., Paris, R., Troll, V. R., and Barker, A. K.: Volcanic and structural evolution of Pico do Fogo, Cape Verde, Geol. Today, 31, 146-152, 2015.

Chirico, G. D., Favalli, M., Papale, P., Boschi, E., Pareschi, M. T., Mamou-Mani, A.: Lava flow hazard at Nyiragongo Volcano, DRC, 2. Hazard reduction in urban areas, Bull Volcanol., 71, 375-387, doi:10.1007/s00445-008-0232-z, 2009.

Copernicus Emergency Management Service $\left({ }^{(} 2014\right.$ European Union), [EMSR111] Volcanic eruption at Fogo Island (Cape Verde), Fogo Island: Grading Map, Detail 1, Monitoring 14, http://emergency.copernicus.eu/mapping/ list-of-components/EMSR111 (last access: 3 March 2016), 2014.

Day, S. F. and Faria, B. V. E.: A geological hazard map of the island of Fogo showing broad distribution of volcanic and other hazards, unpublished Draft Version presented at MIA-VITA workshop in June 2009, 2009 (unpublished data).

Day, S. J., Heleno Da Silva, S. I. N., and Fonseca, J. F. B. D.: A past giant lateral collapse and present-day flank instability of Fogo, Cape Verde Islands, J. Volcanol. Geotherm. Res., 94, 191-218, doi:10.1016/S0377-0273(99)00103-1, 1999.

Day, S. J., Carracedo, J., Guillou, H., Pais Pais, F., Rodriguez Badiola, E., Fonseca, J., and Heleno da Silva, S.: Comparison and cross-checking of historical, archaeological and geological evidence for the location and type of historical and sub-historical eruptions of multiple-vent oceanic island volcanoes, in: The archaeology of geological catastrophes, edited by: McGuire, W., Griffiths, D., Hancock, P., and Stewart. I., Geological Society London, Special Publications, London, 281-306, 2000.

Del Negro, C., Fortuna, L., Herault, A., and Vicari, A.: Simulations of the 2004 lava flow at Etna volcano using the magflow cellular automata model, Bull. Volcanol., 70, 805-812, doi:10.1007/s00445-007-0168-8, 2008.

Dietterich, H. R., Poland, M. P., Schmidt, D. A., Cashman, K. V., Sherrod, D. R., and Espinosa, A. T.: Tracking lava flow emplace- 
ment on the east rift zone of Kîlauea, Hawai'i, with synthetic aperture radar coherence, Geochem., Geophys. Geosyst., 13, 117, doi:10.1029/2011GC004016, 2012.

Dionis, S. M., Melián, G., Rodríguez, F., Hernández, P. A., Padrón, E., Pérez, N. M., Barrancos, J., Padilla, G., Sumino, H., Fernandes, P., Bandomo, Z., Silva, S., Pereira, J. M., and Semedo, H.: Diffuse volcanic gas emission and thermal energy release from the summit crater of Pico do Fogo, Cape Verde, Bull. Volcanol., 77, 10, doi:10.1007/s00445-014-0897-4, 2015.

Favalli, M., Pareschi, M. T., Neri, A., and Isola, I.: Forecasting lava flow paths by a stochastic approach, Geophys. Res. Lett., 32, L03305, doi:10.1029/2004GL021718, 2005.

Favalli, M., Chirico, G. D., Papale, P., Pareschi, M. T., and Boschi, E.: Lava flow hazard at Nyiragongo volcano, D.R.C., 1. Model calibration and hazard mapping, Bull. Volcanol., 71, 363-374, doi:10.1007/s00445-008-0233-y, 2009a.

Favalli, M., Tarquini, S., Fornaciai, A., and Boschi, E.: A new approach to risk assessment of lava flow at Mount Etna, Geology, 37, 1111-1114, doi:10.1130/G30187A.1, 2009b.

Favalli, M., Fornaciai, A., Mazzarini, F., Harris, A., Neri, M., Behncke, B., Pareschi, M. T., Tarquini, S., and Boschi, E.: Evolution of an active lava flow field using a multitemporal LIDAR acquisition, J. Geophys. Res., 115, B11203, doi:10.1029/2010JB007463, 2010.

Favalli, M., Tarquini, S., and Fornaciai, A.: DOWNFLOW code and LIDAR technology for lava flow analysis and hazard assessment at Mount Etna, Ann. Geophys., 54, 552-566, doi:10.4401/ag5339, 2011a.

Favalli, M., Tarquini, S., Papale, P., Fornaciai, A., and Boschi, E.: Lava flow hazard and risk at Mt. Cameroon volcano, Bull. Volcanol., 74, 423-439, doi:10.1007/s00445-011-0540-6, $2011 \mathrm{~b}$.

Favalli, M., Tarquini, S., Fornaciai, A., and Boschi, E.: Dispersion index of topographic surfaces, Geomorphology, 153-154, 169178, doi:10.1016/j.geomorph.2012.02.022, 2012.

Fernandes, R. M. S., Faria, B., and the C4G Team, FOGO-2014: Monitoring the Fogo 2014 Eruption, Cape Verde, EGU General Assembly, Vienna, Austria, 12-17 April 2015, 12709, 2015.

Ferrucci, F., Day, S. J., Hirn, B., Faria, B., and Zoffoli, S.: Multipayload Multi-platform Tactical Monitoring and Evaluation of the 2014 Eruption of Fogo, Cabo Verde, EGU, General Assembly, Vienna, Austria, 12-17 April 2015, 11961, 2015.

Global Volcanism Program (GVP), Report on Fogo (Cape Verde), in: Bulletin of the Global Volcanism Network, edited by: Venzke, E., 20:5, Smithsonian Institution, doi:10.5479/si.GVP.BGVN199505-384010, 1995a.

Global Volcanism Program (GVP), Report on Fogo (Cape Verde), in: Bulletin of the Global Volcanism Network, edited by: Wunderman, R., 20:11, Smithsonian Institution, doi:10.5479/si.GVP.BGVN199512-384010, 1995b.

Global Volcanism Program (GVP), Report on Fogo (Cape Verde), Eruptive History, Smithsonian Institution and US Geological Survey, 2013.

Global Volcanism Program (GVP), Report on Fogo (Cape Verde), in: Bulletin of the Global Volcanism Network, edited by: Wunderman, R., 39:11, Smithsonian Institution, doi:10.5479/si.GVP.BGVN201411-384010, 2014.

González, P. J., Bagnardi, M., Hooper, A. J., Larsen, Y., Marinkovic, P., Samsonov, S. V., and Wright, T. J.: The 2014-2015 eruption of Fogo volcano: Geodetic modeling of
Sentinel-1 TOPS interferometry, Geophys. Res. Lett., 42, 1-8, doi:10.1002/2015GL066003, 2015.

Hanssen, R. F.: Radar Interferometry: Data Interpretation and Error Analysis, Kluwer Academic Publishers, Dordrecht, 328 pp., 2001.

Harris, A. J. L. and Rowland, S. K.: Effusion rate controls on lava flow length and the role of heat loss: A review, Spec. Publ. IAVCEI, 2, 33-51, 2009.

Harris, A. J. L. and Rowland, S. K.: FLOWGO 2012, An Updated Framework for Thermorheological Simulations of ChannelContained Lava, in: Hawaiian Volcanoes: From Source to Surface, Geophysical Monograph Series 208, edited by: Carey, R., Cayol, V., Poland, M. P., and Weis, D., John Wiley \& Sons, Washington, DC, Hoboken, New Jersey, AGU, American Geophysical Union, USA, doi:10.1002/9781118872079, 457-481, 2015.

Harris, A. J. L., Dehn, J., and Calvari, S.: Lava effusion rate definition and measurement: a review, Bull. Volcanol., 70, 1-22, 2007.

Harris, A. J. L., Rhéty, M., Gurioli, L., Villeneuve, N., and Paris, R.: Simulating the thermorheological evolution of channelcontained lava: FLOWGO and its implementation in EXCEL, in: Detecting, Modelling and Responding to Effusive Eruptions, (Spec. Publ.) 426, edited by: Harris, A. J. L., De Groeve, T., Garel, F., and Carn, S. A., Geological Society, London, UK, doi:10.1144/SP426.9, 2015.

James, F. and Winkler, M.: Minuit User's Guide, CERN, Geneva, 52 pp., 2004.

James, M. R., Pinkerton, H., and Applegarth, L. J.: Detecting the development of active lava flow fields with a very-long-range terrestrial laser scanner and thermal imagery, Geophys. Res. Lett. 36, L22305, doi:10.1029/2009GL040701, 2009.

Jenkins, S. F., Spence, R. J. S., Fonseca, J. F. B. D., Solidum, R. U., and Wilson, T. M.: Volcanic risk assessment: Quantifying physical vulnerability in the built environment, J. Volcanol. Geotherm. Res., 276, 105-120, doi:10.1016/j.jvolgeores.2014.03.002, 2014.

Jones, L. K., Kyle, P. R., Oppenheimer, C., Frechette, J. D., and Okal, M. H.: Terrestrial laser scanning observations of geomorphic changes and varying lava lake levels at Erebus volcano, Antarctica, J. Volcanol. Geotherm. Res., 295, 43-54, doi:10.1016/j.jvolgeores.2015.02.011, 2015.

Kauahikaua, J. P. and Tilling, R. I.: Natural Hazards and Risk Reduction in Hawai'i, in: Characteristics of Hawaiian Volcanoes, edited by: Poland, M. P., Takahashi, T. J., Landowski, C. M., US Geological Survey Professional Paper 1801, Reston, Virginia, USA, 397-427, 2014

Kauahikaua, J. P., Margriter, S., Lockwood, J. P., and Trusdell, F.: Applications of GIS to the estimation of lava flow hazards on Mauna Loa Volcano, Hawai 'i, in: Mauna Loa revealed: structure, composition, history, and hazards, edited by: Rhodes, J. M. and Lockwood, J. P., Am. Geophys. Union Geophys. Monogr., 92, 315-325, 1995.

Kilburn, C. R. J.: Lava Flow Hazard and Modelling, in: The Encyclopedia of Volcanoes, Second edition, edited by: Sigurdsson, H., Houghton, B., McNutt, S. R., Rymer, H., and Stix, J., Elsevier, London, San Diego, Waltham, Oxford, 957-969, 2015.

Neves, M. C., Fernandes, R. M., and Adam, C.: Refined models of gravitational potential energy compared with stress 
and strain rate patterns in Iberia, J. Geodyn., 81, 91-104, doi:10.1016/j.jog.2014.07.010, 2014.

Pesci, A., Fabris, M., Conforti, D., Loddo, F., Baldi, P., and Anzidei, M.: Integration of ground-based laser scanner and aerial digital photogrammetry for topographic modelling of Vesuvio volcano, J. Volcanol. Geotherm. Res., 162, 123-138, doi:10.1016/j.jvolgeores.2007.02.005, 2007.

Poland, M. P.: Time-averaged discharge rate of subaerial lava at Kîlauea Volcano, Hawai'i, measured from TanDEM-X interferometry: Implications for magma supply and storage during 2011-2013, J. Geophys. Res.-Earth, 119, 5464-5481, doi:10.1002/2014JB011132, 2014.

Poland, M. P., Orr, T. R., Kauahikaua, J. P., Brantley, S. R., Babb, J. L., Patrick, M. R., Neal, C. A., Anderson, K. R., Antolik, L., Burgess, M., Elias, T., Fuke, S., Fukunaga, P., Johanson, I. A., Kagimoto, M., Kamibayashi, K., Lee, L., Miklius, A., Millon, W., Moniz, C., Okubo, P. G., Sutton, A. J., Takahashi, T. J., Thelen, W. A., Tollett, W., and Trusdell, F. A.: The 2014-2015 Pāhoa lava flow crisis at Kîlauea Volcano, Hawai'i: Disaster avoided and lessons learned, GSA Today, 26, 4-10, doi:10.1130/GSATG262A.1, 2016.

Quental, L., Soares, A., and Gaspar, J. L.: A lava flow simulation model using a GIS as a contribution for hazard assessment as Fogo island, Cabo Verde, Rev. Port. Vulcanol., 1, 149-154, 2003.

Ramalho, R. S., Winckler, G., Madeira, J., Helffrich, G. R., Hipolito, A., Quartau, R., Adena, K., and Schaefer, J. M.: Hazard potential of volcanic flank collapses raised by new megatsunami evidence, Sci. Adv., 1, e1500456, doi:10.1126/sciadv.1500456, 2015.

Ribeiro, O.: A Ilha do Fogo e as suas erupcoes (The island of Fogo and its Eruptions), Memorias, serie geografica I. Junta de Investigacoes do Ultramar, Ministerio do Ultramar, Lisbon, 319 pp., 1960.

Richter, N., Favalli, M., de Zeeuw-van Dalfsen, E., Fornaciai, A., Fernandes, R. M. S., Pérez, N. M., Levy, J., Silva Victória, S., and Walter, T. R.: A post-2015 lava flow hazard map for Fogo Volcano, Cabo Verde, GFZ Data Services, doi:10.5880/GFZ.2.1.2016.001, 2016.

Riegl: 3D Terrestrial Laser Scanner Riegl VZ-4000/Riegl VZ-6000, General Description and Data Interfaces, Manual, RIEGL LMS GmbH, Austria, 508 pp., 2013.

Silva, S., Cardoso, N., Alfama, V., Cabral, J., Semedo, H., Pérez, N. M., Dionis S., Hernández, P. A.,Barrancos, J., Melián, G. V., Pereira, J. M., and Rodríguez, F.: Chronology of the 2014-15 volcanic eruption on the island of Fogo, Cape Verde, EGU General Assembly, Vienna, Austria, 12-17 April 2015, 13378, 2015.

Slatcher, N., James, M. R., Calvari, S., Ganci, G., and Browning, J.: Quantifying effusion rates at active volcanoes through integrated time-lapse laser scanning and photography, Remote Sens., 7, 14967-14987, doi:10.3390/rs71114967, 2015.

Tarquini, S. and Favalli, M.: Mapping and DOWNFLOW simulation of recent lava flow fields at Mount Etna, J. Volcanol. Geotherm. Res., 204, 27-39, doi:10.1016/j.jvolgeores.2011.05.001, 2011.
Tarquini, S. and Favalli, M.: Uncertainties in lava flow hazard maps derived from numerical simulations: The case study of Mount Etna, J. Volcanol. Geotherm. Res., 260, 90-102, doi:10.1016/j.jvolgeores.2013.04.017, 2013.

Tarquini, S. and Favalli, M.: Simulating the area covered by lava flows using the DOWNFLOW code, in: Detecting, Modelling and Responding to Effusive Eruptions, (spec. publ.) 426, edited by: Harris, A. J. L., De Groeve, T., Garel, F., and Carn, S. A., Geological Society, London, UK, doi:10.1144/SP426.15, 2015.

Texier-Teixeira, P., Chouraqui, F., Perrillat-Collomb, A., Lavigne, F., Cadag, J. R., and Grancher, D.: Reducing volcanic risk on Fogo Volcano, Cape Verde, through a participatory approach: which outcome?, Nat. Hazards Earth Syst. Sci., 14, 2347-2358, doi:10.5194/nhess-14-2347-2014, 2014.

Torres, P. C., Madeira, J., Silva, L. C., Brum da Silveira, A., Serralheiro, A., and Mota Gomez, A.: Carta geologica das erupções historicas da ilha do Fogo: revisão e actualização. A erupcao vulcanica de 1995 na Ilha do Fogo, Cabo Verde, Publ. IICT, Lisboa, 119-132, 1997.

United Nations: Post-Disaster Needs Assessment (PDNA), Fogo Volcanic eruption 2014-2015, available at: http://www.un.cv/ files/PDNAREPORT_EN.PDF, (last access: 9 February 2016), 2015.

Verhoeven, G.: Taking computer vision aloft - archaeological threedimensional reconstructions from aerial photographs with photoscan, Archeol. Prospect., 18, 67-73, doi:10.1002/arp.399, 2011.

Walker, G. P. L., Huntingdon, A. T., Sanders, A. T., and Dinsdale, J. L.: Lengths of lava flows, Phil. T. R. Soc. Lond., 274, 107-118, doi:10.1098/rsta.1973.0030, 1973.

Westoby, M. J., Brasington, J., Glasser, N. F., Hambrey, M. J., and Reynolds, J. M.: 'Structure-from-Motion' photogrammetry: A low-cost, effective tool for geoscience applications, Geomorphology, 179, 300-314, doi:10.1016/j.geomorph.2012.08.021, 2012.

Wolfe, E. W., Garcia, M. O., Jackson, D. B., Koyanagi, R. Y., Neal, C. A., and Okamura, A. T.: The Puu Oo eruption of Kỉlauea Volcano, Episodes 1-20, January 3, 1983, to June 8, 1984, in: Volcanism in Hawaii, edited by: Decker, R. W., Wright, T. L., and Stauffer, P. H., US Geol. Surv. Prof. Pap. 1350, 471-508, US Geol. Surv., Reston, VA, USA, 1987.

Worsley, P.: Physical geology of the Fogo volcano (Cape Verde Islands) and its 2014-2015 eruption, Geol. Today, 31, 153-159, doi:10.1111/gto.12102, 2015.

Zebker, H. A., Rosen, P., Hensley, S., and Mouginis-Mark, P. J.: Analysis of active lava flows on Kilauea volcano, Hawaii, using SIR-C radar correlation measurements, Geology, 24, 495-498, doi:10.1130/0091-7613(1996)024<0495:AOALFO>2.3.CO;2, 1996.

Zumberge, J. F., Heflin, M. B., Jefferson, D. C., Watkins, M. M., and Webb, F. H.: Precise point positioning for the efficient and robust analysis of GPS data from large networks, J. Geophys. Res., 102, 5005-5017, doi:10.1029/96JB03860, 1997. 